\title{
Johannes Gabriel Granö and his Cartography- Oriented Landscape Research. A Reviewing Appreciation.
}

\author{
Holger Helm, Manfred F. Buchroithner* \\ Dresden University of Technology, Institute for Cartography, Helmholtzstrasse 10, 01069 Dresden, Germany
}

\begin{abstract}
The present article shall bring to mind the extraordinary stimuli given by Johannes Gabriel Granö (1882 1956) to international landscape research through his exceptionally wide spectrum of studies. It begins with his expeditions into the Altai Mountains and to Northwestern Mongolia at the beginning of the 20th century and his multifaceted publications about their results - also in difficult times - like in 1945. The paper further treats Granö's pioneering works about geography and cartography of Estonia at the beginning of the 1920s, his methodological and applied articles about physiognomic landscape characteristics, both in detailed as well as in overview scales - and mostly demonstrated in his Finnish motherland. Granö's monograph „Reine Geographie“ / „Pure Geography“ - first published in German language in 1929 - revived, after its translation into English (in 1997), half a century later eager interest in his activities. In 2002, the Universities of Turku (Finland) and Tartu (Estonia) responded to this development through the establishment of a Granö Centre as a site of encounters and exchanges. In the context of the European Landscape Convention (ECL) it becomes obvious how far J.G. Granö was ahead of his time.
\end{abstract}

\section{Keywords:}

Johannes Gabriel Granö, cartography-oriented landscape research, Altai and Northwest Mongolia, Tartu, Estonia, Atlas of Finland, Pure Geography, landscape physiognomy, determination of geographic regional, entities, virtual landscape character, landscape perception, European Landscape Convention (ECL)

*Corresponding author. Email: manfred.buchroithner@tu-dresden.de

(C) The Authors. 2018. Landscape Online. This is an Open Access article distributed under the terms of the Creative Commons Attribution License (http://creativecommons.org/licenses/by/4.0), which permits unrestricted use, distribution, and reproduction in any medium, provided the original work is properly cited. 


\section{Preface}

The present paper was written during the turn of the years 2015 to 2016. It is intended to make reference to the monograph „Das Formengebäude des nordöstlichen Altai“ [„,Geomorphological Outlineof the Northeastern Altai Mountains"], published in 1945, which concluded the German-phrased works of Johannes Gabriel Granö about the Altai Mountains, as well as to the 60th anniversary of his decease in 1956. Ongoing research activities of the second author and his colleagues in the Altai Mountains since 1995 (Prechtel \& Buchroithner, 2003; Vázquez Arias, 2013) inevitably lead to an intense dwelling upon Granö's oeuvre and, hence, also gave reason and motivation for the present article.

\section{A Finn impresses the German-speaking geography - J.G. Granö in retrospect}

In his book „Origin of Landscape Science“, published in 2003, Granö's youngest son Olavi sets forth the extraordinary thematic spectrum of his father by reporting from the jubilee event „125 Jahre Gesellschaft für Erdkunde zu Berlin“ [„125 Years Geographical Society in Berlin"] in 1953 the following little anecdote happening during the introduction of the Society's special guest J.G. Granö: „The society's chairman, Professor EdwinFels, deliberately introduced him ... as two separate historical figures, and some people present were quite astounded to find that they were one and the same person. Similary, the modern Russian scientists who refer to the archaeological or geological work of Gavriel Ivanovich Grane in Central Asia woulds carcely be aware at all of the content of his methodological work" (Granö, 2003).

How did J.G.Granö reach this exceptional professional width which distinguished him during his lifetime and beyond? Being born in the West-Finnish town of Lappo/Lapua in 1882, his family moves to the Siberian town of Omsk in 1885. As Lutheranian pastor, Granö's father looks after the Finnish population living there. After school attendance in Finland from 1892 until 1900 J.G. Granö studies in Helsinki and works there as university assistant from 1902 to 1912. However, until the death of his father in 1913 J.G. Granö spends all his summers in Siberia and can, thus, deepen his knowledge about the country and its people as well as its language(s).

Already in 1905 he publishes his first scientific article about „The Finnish Colonies in Siberia“in Fennia, the journal of the Finnish Geographic Society, thereby paying great attention to the inclusion of a German Zusammenfassung (i.e. abstract; Granö, 1905). His motivation: One of Granö's academic teachers in Finland was Johan Evert Rosberg who had studied geography, in particular geomorphology, in Germany under Albrecht F.K. Penck. Penck's intellectual edifice was of such strong influence that during this time the glacial and bedrock morphology based on his views molds the Finnish Geography. According to Pentti Yli-Jokipii this initiates a phase of a close "German connection" in Finnish Geography which lasted for several decades (Yli-Jokipii, 1991). Between 1905 and 1909 J.G. Granö undertakes a series of expeditions, setting off from Omsk until Northern Mongolia. His last research trip of this period is charged and funded by the Finnish-Ugrian Society, a learned association that, since its foundation in 1883 , set themselves to promote the sciences dealing with Uralian and Altaic languages, the ethnography of their speakers and the investigation of their history. Correspondingly, J.G. Granö's article about „Archäologische Beobachtungen von meiner Reise in Südsibirien und der Nordwestmongolei im Jahre 1909“ [„Archaeological Observations during my Travel through Southern Siberia and Northwestern Mongolia in 1909"] is published in the Journal de la Société Finno-Ougrienne, 25/1910. Since it is written in German, the author immediately attracts the attention of the renowned journal Dr. A. Petermanns Mitteilungen issued by Justus Perthes 'Geographischer Anstalt in Gotha, Germany.

In the same year, 1910, J.G. Granö publishes his doctoral thesis entitled „Beiträge zur Kenntnis der Eiszeit in der nordwestlichen Mongolei und einigen ihrer 
südsibirischen Grenzgebirge. Geomorphologische Studien in den Jahren 1905, 1906, 1907, und 1909“ [„Contributions to the Knowledge about the Ice Age in Northwestern Mongolia and some of its South Siberian Border Mountains. Geomorphological Studies in the Years 1905, 1906, 1907, and 1909,,]. This 230-pages monograph is also written in German and issued by Fennia (Granö, 1910). The Munich-based high-mountain expert and Tian Shan specialist Gottfried Merzbacher reviews this treatise - again in Dr. A. Petermanns Mitteilungen -testifying Granö's dissertation high value due to „der Fülle wertvollen Tatsachenmaterials" ["the abundance of valuable facts"] in connection with "einer vollständigen Erforschungsgeschichte jener Gegenden" [,a complete exploration history of those regions"] (Merzbacher, 1911). In this context, Merzbacher, himself fluently speaking Russian, emphasizes: „Der Verfasser hat aus der zerstreuten und schwer zugänglichen russischen Literatur über jene Gebiete alles herausgezogen und zusammengetragen, was frühere Reisende in Bezug auf glazialgeologische Verhältnisse beobachtet haben" [,The author extracted anything and everything from the scattered and hard-toaccess Russian literature about these regions what previous explorers had already observed about the glacial-geological conditions,,] and condensed his own researchusing „gut gewählte, charakteristische und beweiskräftige, auch technisch gelungene photographische Aufnahmen“ [,well-selected, characteristic and conclusive, also technically well-made photographs,,]. Merzbacher's marginal remark regarding „eine mit unserer gewohnten wissenschaftlichen Terminologie manchmal nicht übereinstimmende Ausdrucksweise " [„terminology partly not compliant with our commonway of scientific phrasing,n] can today be interpreted as one of the first hints to J.G. Granö's extraordinary capabilities concerning landscape perception and reflection (cf. additional comments further back).

Between 1911 und 1913 J.G. Granö travels the Far East including Japan as well as the mountain regions of Tian Shan and Caucasus. Subsequently he moves with his wife Helmafor three years to Omsk. From there, funded by a travel grant from Helsinki University, he carries on his geomorphological and glacial-geological investigations in the Russian Altai. Figure 1 gives an overview over the Altai routes of J.G. Granö in the years 1906 through 1916 (Buttimer, 2010).

His broad knowledge about Altai and Northwest Mongolia is further demonstrated in 1912 - 1914 by more publications, mainly in German. Again, the Finno-Ugrian Society and the Gesellschaft für Erdkunde zu Berlin [Geographical Society in Berlin] in their journal Erdkunde provide an appropriate stage for him:
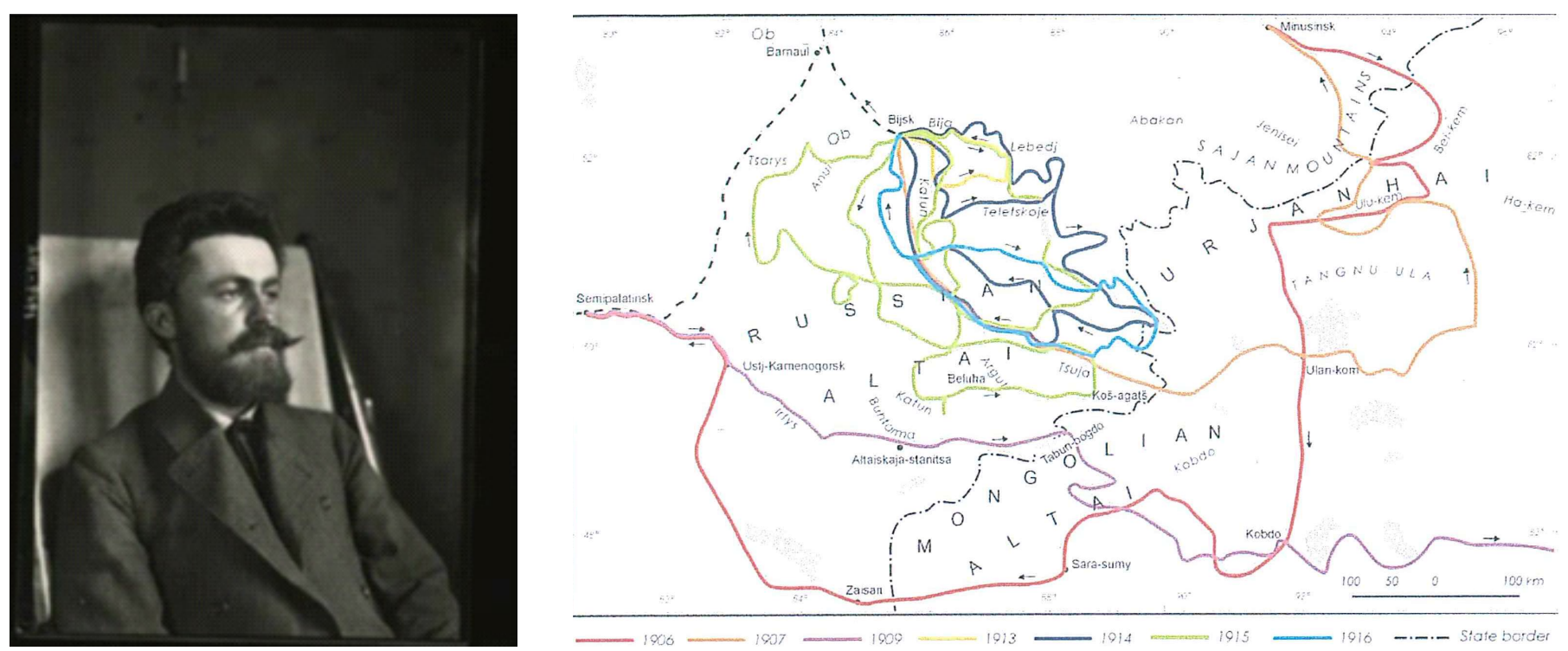

Figure 1: Left: J.G. Granö at the age of 27 (1909), and right: his Altai routes 1906 - 1916 (Buttimer, 2010) 
Granö, J.G: Die Nordwestmongolei. Eine geographische Skizze. Zeitschrift der Gesellschaft für Erdkunde zu Berlin, 1912, pp. 561-588.

Granö, J.G: Über die geographische Verbreitung und die Formen der Altertümer in der Nordwestmongolei. Journalde la Société Finno-Ougrienne 28/2/1912,pp. 1-55.

Granö, J.G: Morphologische Forschungen im östlichen Altai. Zeitschrift der Gesellschaft für Erdkunde zu Berlin, 1914, pp. $329-341$.

In 1916 J.G. Granöis again back to Finland. Due to political reason, for the rest of his life Siberia will not be accessible to him. He is now occupying himself with geographic studies about his mother country and primarily exploits his collections of Altai material. Consequently, in 1921 comprehensive publications appear - in Finnish and Swedish- both under the title "Altai“. They demonstrate not only Granö's excellent capability to describe landscapes but also to phrase his reflections in a poetic way (cf. Buttimer, 2010).

In Germany it is Paul Fickeler who, in 1925, publishes his PhD Thesis about "Der Altai“ without ever having been there (Fickeler, 1925; Terheyden, 1994), who benefits from J.G. Granö. Possibly, in this context he might also have had contact with him (see below, Fig. 6).

A turning point in J.G. Granö's subject-specific setting of priorities is the year 1919 (Granö, 2003). The university in the Estonian town of Dorpat/ Tartu appoints him, meanwhile habilitated, as professor. Granö is going to hold this position until 1923 and postpones - except of the finalisation of the aforementioned publications - further papers about Altai. They will only be published in the 1940s. Instead, he involves himself intensively in the international discussion about Geography as an (independent) scientific discipline as well as about the views of leading German geographers, most of all Otto Schlüter und Siegfried Passarge, regarding landscape analysis and address, and links them with his own views.
On this basis a series of studies concerning Estonia originate. Fig. 2 shows the cover of the Estonian journal Loodus (Nature) and the German opening citation of issue 2/1922 about the landscape units of Estonia selected by J.G. Granö (Granö, J.G., 1922). His Estonian creative period forms the basis for his later works regarding geographic and cartographic methodology.

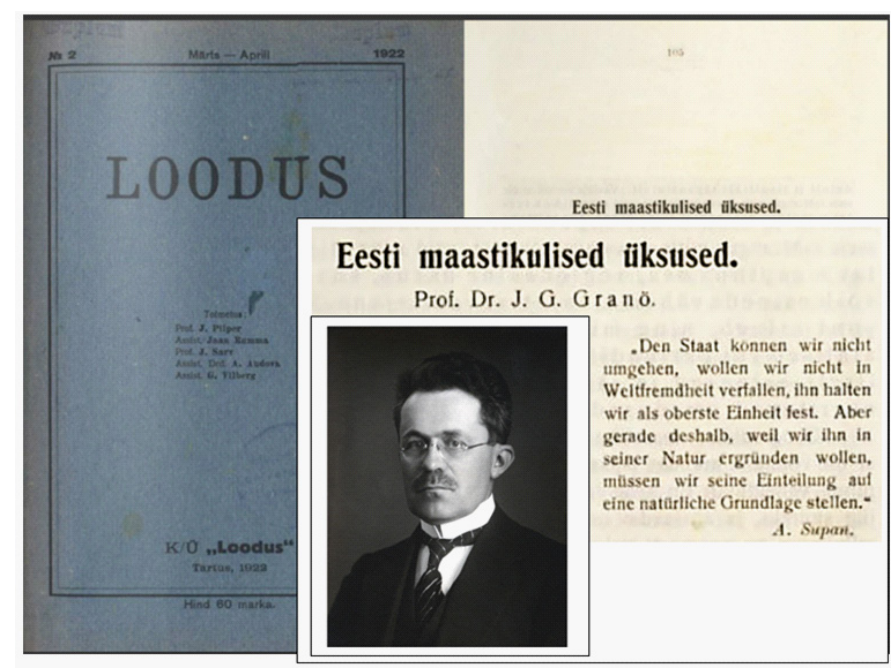

Figure 2: Left: J.G.Granö at the age of 42 (1924), and lower right corner: Cover and opening ciation of Loodus issue 1922/2

In 1923 J.G.Granö is appointed Corresponding Member of the Gesellschaft für Erdkunde zu Berlin [Geographical Society in Berlin], finishes his occupation in Tartu and goes back to Finland, to the University of Helsinki. At J.G. Granö's 50th birthday his Estonian student Michael Haltenberger gives a short but concise appraisal in German language: „Die verdienstvolle Pionierarbeit J.G. Granös hat eine geographische Schule in Estland begründet" [„The meritorious pioneering work of J.G. Granö founded a Geographic School in Estonia.] (Haltenberger, 1934). - From his Helsinki base J.G. Granö contributes substantially to the compilation of the Atlas of Finland and even acts as its editor (1923-25).

In 1926 J.G. Granö changes to the University of Turku. Here he completes his treatise about „Reine Geographie“ [„Pure Geography“] which is published in German in 1929 - one year prior to the edition in his Finnish mothertongue (Granö, 1929). For this book he extensively uses his insights from fieldwork 
in Estonia and Finland but also the many landscape impressions from his research stays in Central Asia. For the acquisition and description of visually comparable landscape features in their spatial position and distribution he develops an encoding system under the labelling "Landschaftsformel" [,Landscape Formula“; see below „Die geographischen Gebiete Finnlands"]. Moreover, J.G. Granö captures, within the scope of his "Nähelehre“ [„Proximate Science"] - with a thematic width and cartographic complexity so far unknown - visual, acoustic, olfactoric and tactile-haptic properties which are acquirable in the immediate proximity to one's position until a distance of approx. 100-200 metres („Kleinräume“ - "detailed-scale units") without special measuring equipment (i.e. „sinnlich“ - „by sense perception“). This approach includes movable objects (vehicles, cattle) as well as the seasonal changes. Figure 3a and $3 \mathrm{~b}$ show exemplary mappings of "Geruchsund Gehörserscheinungen" (odour and acoustic phenomena) in a part of the Finnish Valosaari Island $\left(27^{\circ} \mathrm{E}, 52^{\circ} \mathrm{N}\right)$, elaborated already in 1923 .J.G. Granö emphasizes: „... die Nähelehre stellen wir als gleichwertig neben die Landschaftskunde" $[, \ldots$ we put the proximate science equivalently beside landscape science"] (Granö, 1929). Overall, he attaches much importance to systematic studies: „Meine eigentliche Kritik richtete sich aber vornehmlich gegen eine Beschreibung, die ohne Plan und Ziel verfährt und durch ihre Weitschweifigkeit ermüdet“ [„My actual critics aimed, however, at a description that proceeds without plan and aim and wearies through its prolixity"](Granö, 1929).

The reactions of the German-speaking geographic community were not long in coming. As one of the first, the Austrian Hugo Hassinger, then professor at the University of Freiburg im Breisgau, discusses, already in Issue 5/1930 of the journal "Geographische Zeitschrift" the term "Reine Geographie" and states: "Die Lokalisierung der Erscheinungen in der Karte und die quantitative Wertung der Qualitäten, also die Erkennung und Darstellung des Charakteristischen ist Hauptaufgabe des Geographen. Das sind keine neuen Gedanken, doch tragen sie neues Gewand. Nun aber kommt das Neue: Granö stellt die Erscheinungen in den Vordergrund ... (Wärme, Feuchtigkeit, Druck, Laute, Gerüche)" [,Locating of phenomena in a map and quantitative assessment of qualities as well as the identification and depiction of their characteristics is a major task of a geographer. These are no new

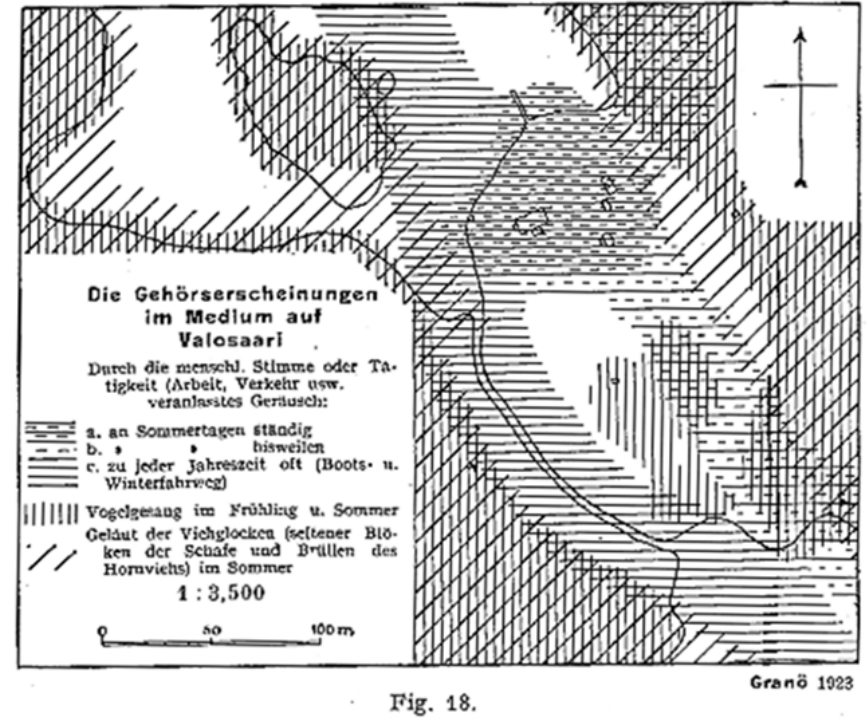

Dic schrnffierten Fthehen werded durch die 25 m-Enchelieungs. oder Wirkuagekurven dez betr.

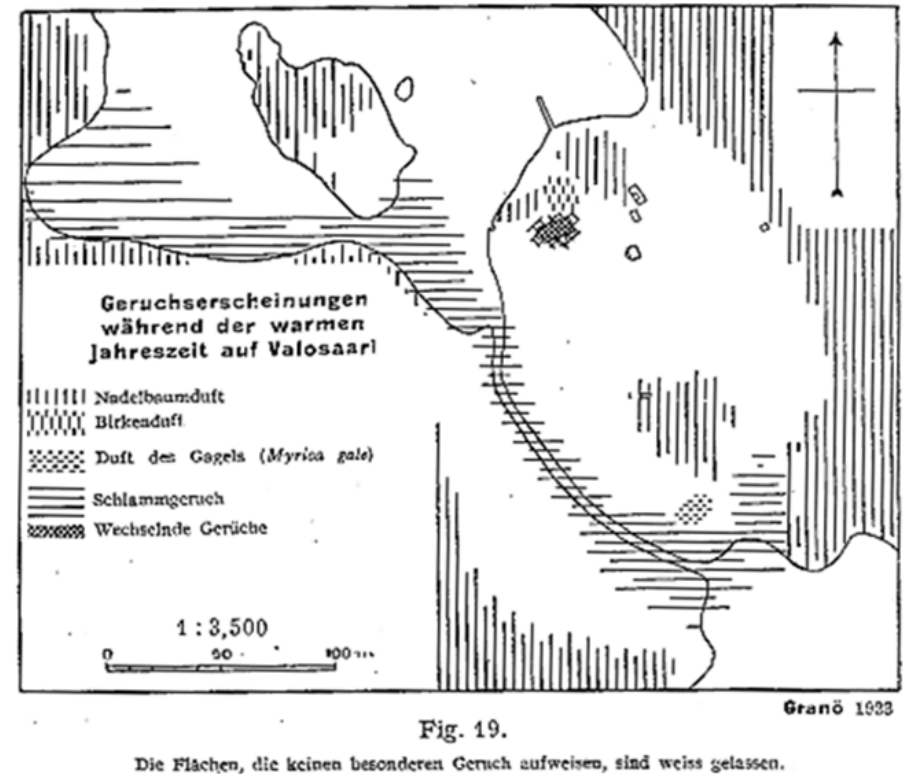

Die Flachen, dic keinea besonderen Genuch aufweisen, sind weiss selassen.

Figure 3: Mapping examples of the Finnish Valosaari Island concerningauditory (left) and olfactory phenomena (right) (Granö, 1929). 
insights but they are now wearing a new dress. But here comes the new: Granö puts the phenomena into the foreground ... (warmth, humidity, (air) pressure, noises, odours),,]. In conclusion he notes expressly: Granö "hat uns ein wertvolles kartographisches Material für die Syn-these geboten“ [„offered us valuable cartographic material for the synthesis,,] and desires the continuation of his efforts to „die erklärte Ganzheit auch zum Leben zu erwecken“ [„,also arouse the explained entirety"] (Hassinger, 1930). In Switzerland Fritz Jaeger, who has beenassuming the Chair of Geography at the University of Basel since 1928, reports on the above issues. He considers J.G. Granö's „Reine Geographie“ an „inhaltsreiche und originelle Schrift" [,an inventive paper, rich in substance"] (Jaeger, 1931). In Germany the Geographic Institute of Technische Hochschule Dresden intensively analyses the treatise of Granö and concludes that his views are indeed connate with those of the contemporary German opinion leaders in geographic landscape science Otto Schlüter and Siegfried Passarge - „in ihrer Weise, aber doch wieder selbständig und eigenartig " [,,in their way,but independently and peculiarly,] (Bürger, 1935).

Siegfried Passarge, whose oeuvre had been intensively studied by Granö, remains critical, especially towards J.G. Granö's formulistic landscape addressing. He is not able to join Hugo Hassinger in considering the concise keys better than the long compound word combinations. Moreover, Passarge criticises content gaps concerning climate, groundwater conditions and hypsometry. In his view one can „kaum im Zweifel sein, daß die Methode, die Landschaften mit Hilfe von Symbolen auszudrücken, unmöglich den Vorzug verdient gegenüber der unmittelbaren Benennung " [,hardly doubt that the method to describe landscapes by means of symbols deserves in no way preference versus a direct denotation,](Passarge, 1931).

Already in 1931 J.G. Granö virtually accommodates Hassinger's wish for further development and publishes "Die geographischen Gebiete Finnlands" [„The Geographic Regions of Finland“] (Granö, 1931. With the use of the landscape formula developed in "Reine Geographie“, he issues - again in German! an adequate geographic structuring of his mother country. It originates from the conceptual works for an intended second edition of the Atlas of Finland edited by the Geographic Society of Finland, dating back to 1929.

J.G. Granö defines domains and provinces which are based on nothing less but 106 „Örtlichkeiten" („geographische Individuen“) [„localities“
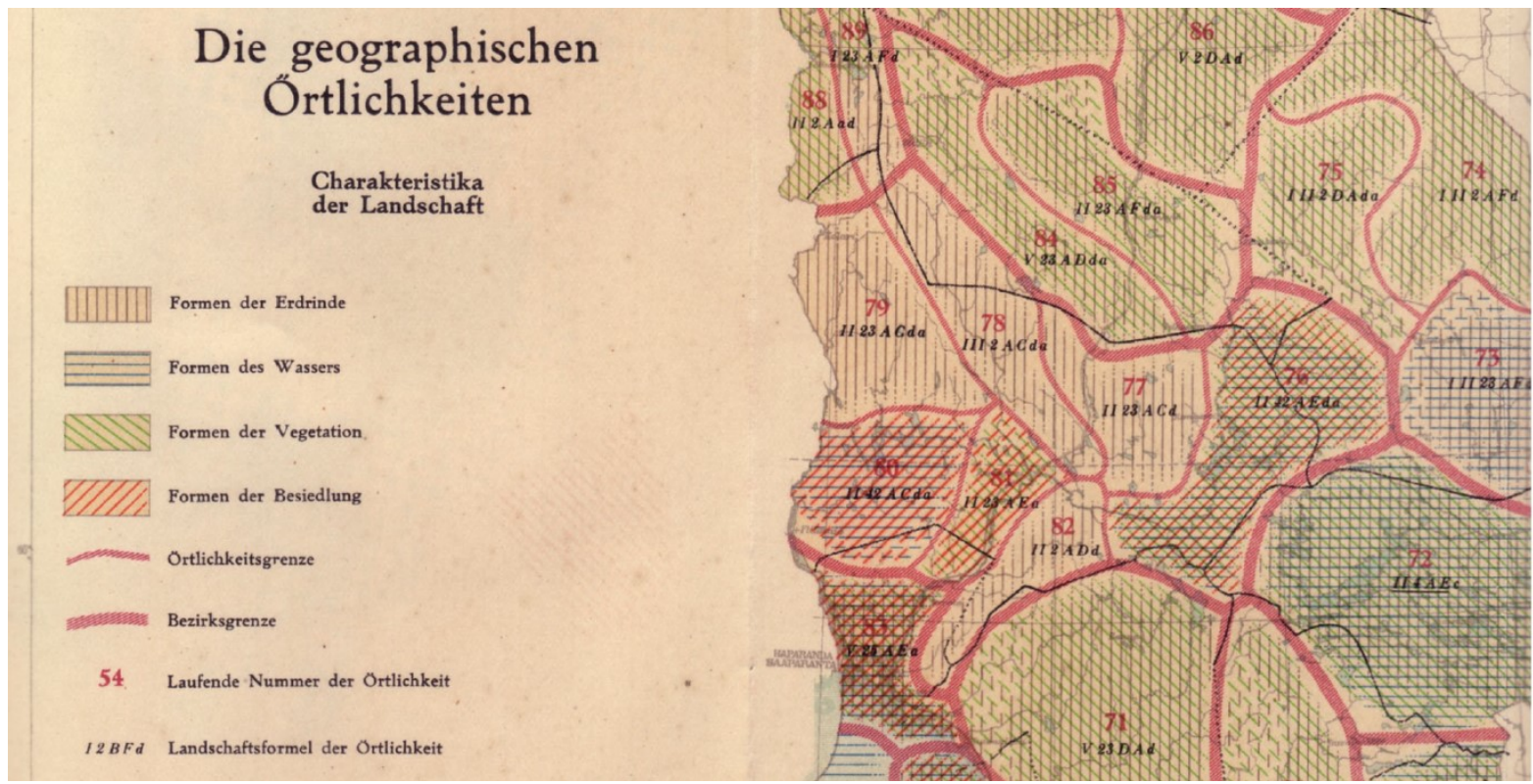

Figure 4: Portion of „Die geographischen Gebiete Finnlands“ [,The Geographic Regions of Finland“], original scale 1:3,000,000 (Granö, 1931). 
(„geographic individuals")]. He calls his derivation of 65 landscape types "landscape-morphological“ and "physiognomic", "da wir bei ihrer Bestimmung nur die sichtbaren Züge beachten" [,since for their determination we are only considering their visible features"]. In his view he sees landscapes mostly molded by water and the ones determined by relief and by vegetation, complemented by „Formengebiete der Besiedlung“ [„morphological regions of settlements"]. The latter ones he subsumes under the term "umgeformter Stoff" ["transformed/reshaped substance“] - implying the natural conditions changed by technical influencing. Elements of the formulas for the characteristics of surface forms are Roman figures, for water bodies Arabic ones. Vegetation units are coded by Latin capital letters, built-up areas by small letters.

Implications of the Formula Symbols

I - High mountains (altitude differences H. > 200 $\mathrm{m})$,

II Mountains (H. $50-200 \mathrm{~m}$ ),

III Hilly terrain (H. $20-50 \mathrm{~m}$ ),

IV Low rolling terrain (H. $10-20 \mathrm{~m})$,

V Flat country $(H .<10)$,

VI Lowlands,

VII Valley (valley depth $>50 \mathrm{~m}$ ), Tableland (with a raise of mostly $>50 \mathrm{~m}$ ).

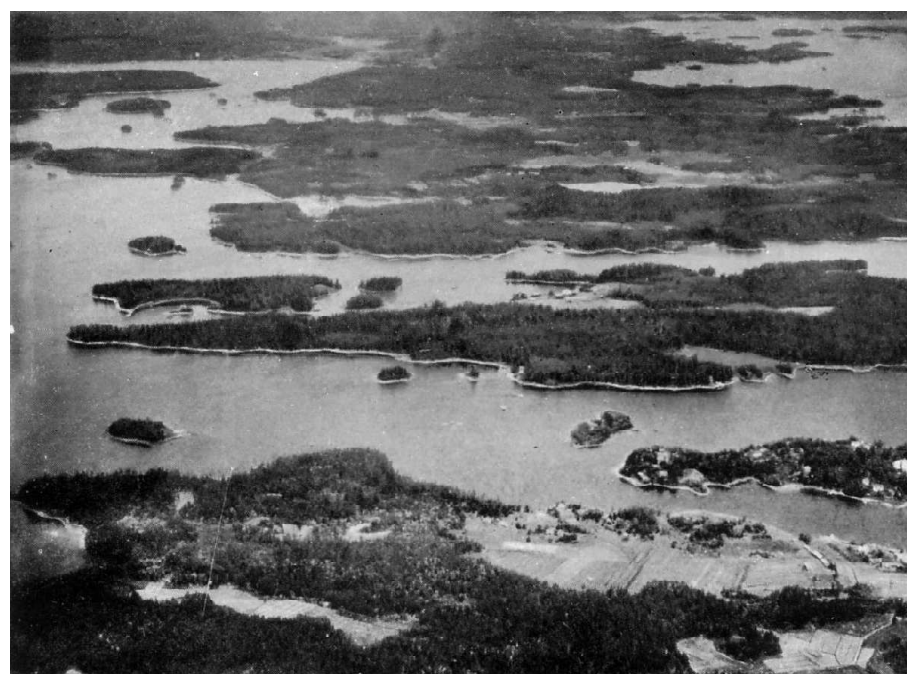

1 Open lake or high sea,

2 Watercourse,

3 Lakes,

4 Lake chain,

5 Coastal and skerry waters,

6 Region with very few waterforms only.

A Forest land,

B Shrubland,

C Swamp woodlands (with spruce stands),

D Spruce pine mire and matgrass moor (peat and dwarf shrubs),

E Grassland (natural and cultivated grasses resp. field plants),

a - Row-house settlement

b - Cluster settlement,

c - Isolated dwellings,

d - Only sporadically occurring artificial landform. Mostly trails or roads.

The superposition of these thematic layers named „analytische Formengebiete" [,analytical morphological regions"] by J.G. Granö leads to a "kartographische Gebietssynthese" [„cartographic regional synthesis"]. The latter one represents the basis for the "Bestimmung der geographischen Gebietsganzheiten“ ["determination of geographic regional entities"] with the demarcation of

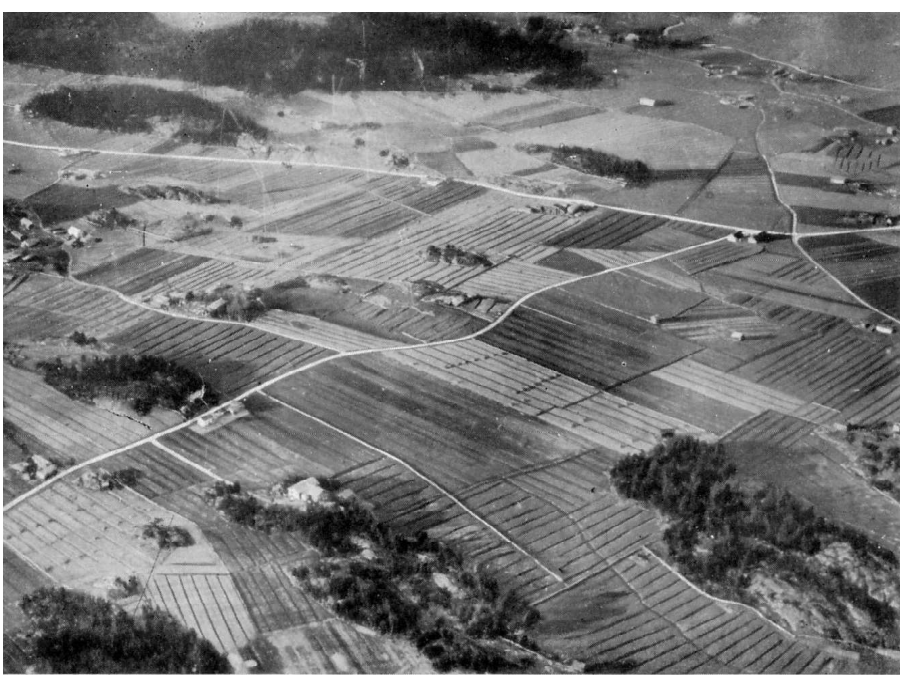

Figure 5: Aerial photographs of „Örtlichkeit“ [„location“] No. 17 (IV 5 AE bc) Borga, Pellinge Skerries (left) and „Örtlichkeit“ No. 3 (V EAF c) Raisio, 6 km NW of Turku (right), (Granö, 1931). 
„Homogenitätsgraden“ [„degrees of homogeneity“] and "Übergangszonen" [,transition zones“]. In this context Granö states: „Je umfangreicher das betreffende Gebiet ist, um so unentbehrlicher ist bei der Gebietseinteilung die Karte und um so ausgesprochener gestaltet sich die Bildung von Ganzheiten zu einem rein kartographischen Verfahren."[,The more comprehensivea region is, the more indispensible is a map for landscape zonation and the more explicitly the creation of entireties becomesa purely cartographic procedure."]

Here, J.G. Granö again puts particular emphasis on visualisation and adds plenty of oblique airphotos of the respective landscapes - J.G. Granö calls them "Örtlichkeiten" [,locations"] - to text and maps. Figure 5 shows two examples.

In 1932 Hans Schrepfer, at that time geographer in Frankfurt, considers J.G. Granö's „Die geographischen Gebiete Finnlands" as "bedeutungsvoll“ [,important"] and sees them "methodisch als praktische Erprobung der in 'Reine Geographie' entwickelten Theorien“ [,as a practical testing of the theories developed in 'Reine Geographie'] (Schrepfer, 1932).

Years later, J.G. Granö's Estonian student and later successor at Tartu University, August Tammekann, comments this: "Die theoretische Grundlage von J.G. Granös System war erheblich logischer und exakter als die von Passarge. Granö führte auch kartotechnische Erneuerungen bei der Gebietsaufteilung ein, nahm Landschaftsschemen in Gebrauch“ [„The theoretical basis of J.G. Granö's system was significantly more logic and exact than Passarge's. Granö introduced carto-technical innovations for the territorial allocation, he [also] took landscape schemes into use."] (Yli-Jokipii, 1991).

The following year J.G. Granö still keeps dealing with this topic of the differentiation of geographic regions. He presents it at the International Geographical Congress in Warsaw 1934 (Granö, 1934) and in 1935 writes a paper entitled „Geographische Ganzheiten“ [„Geographic Entireties"] for Dr. A. Petermanns Mitteilungen. In this article he reflects his
„Landschaftsformel, die die Art des Nebeneinander auftretens der Formenkomplexe in der Landschaft in Kürze widergibt" [,landscape formula which reflects the side-by-side occurrence of the morphological complexes in the landscape in a nutshell,,] and resumes: „Diese beiden Welten, die erlebte und die gemessene sind bei unserer Arbeit gleicherweise wesentlich und bedeutsam " [,These two worlds, the experienced and the measured ones, are equally essential and important for our work.,.] (Granö, 1935). 1937 his treatise "Gehöfte und Siedlungen in Finnland " [„,Farmsteads and Settlements in Finland"] is published (Granö, 1937). Hans Schrepfer considers this „erstmalig eine geographische Siedlungskunde Finnlands" [,a first-time geographic settlement science of Finland,"] and acknowledges this monograph as „wichtige anthropogeographische Ergänzung" [,important anthropo-geographic supplement" of "Die geographischen Gebiete Finnlands" (Schrepfer, 1939).

Subsequently J.G. Granö begins to elaborate the field-materials of his former Altai expeditions, so far unused for many years. Aimo Kalervo Merisuo, who supported already as a student Granö through statistical analyses and cartographic work for „Die geographischen Gebiete Finnlands", compiles on his behalf the collection "Itinerarien und Landschaftsprofile J.G. Granös aus Uranchai (TannuTuwa) und der Nordmongolei" [,Itineraries and Landscape Profiles of J.G. Granö from Uranchai (Tannu-Tuwa) and Northern Mongolia"], published in 1938 (Merisuo, 1938). Also in the future Merisuo will be of enormous help to Granö.

In 1941 eventually a 300-pages monograph entitled „Mongolische Landschaften und Örtlichkeiten. Eine Geographie physiognomischer Typen und einheitlicher Räume nach Reisebeobachtungen und Wegeaufnahmen in Uranchai (Tannu-Tuwa) und der Nordmongolei aus den Jahren 1906, 1907 und 1909“ [,Mongolian Landscapes and Localities. A Geography of Physiognomic Types and Homogeneous Spaces Based on Field Observations in the Years 1906, 1907 and 1909"] is printed (Granö, 1941). It triggers appreciative reviews by Gustav FochlerHauke and Fritz Machatschek in the Zeitschrift der 
Gesellschaft für Erdkunde and in the Geographische Zeitschrift. The history-charged dramatic year 1945 sees the publication of J.G. Granö's comprehensive book „Das Formengebäude des nordöstlichen Altai" [,The Geomorphological Systemof the Northeastern Altai Mountains"] in the series of the publications of the Geographic Institute of Turku University (Granö, 1945). It lays the foundation for a systematic geographic-cartographic survey of the Altai Mountains. Figure 6 shows the cover of this monograph with an inscription of J.G. Granö for the aforementioned Paul Fickeler.

After World War II J.G. Granö deals with regionalgeographic studies and their applications and tasks in Finland as well as - again - with the plateaus

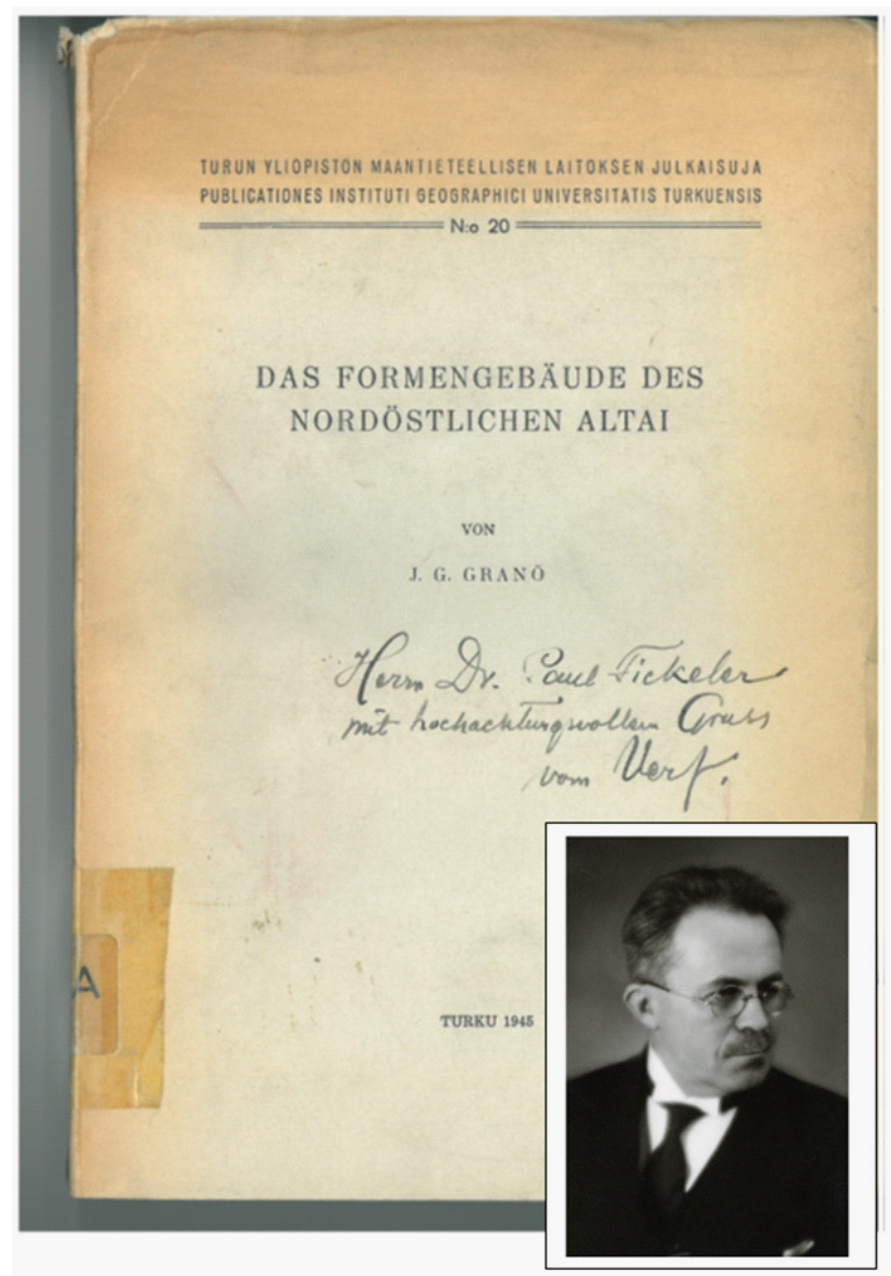

Figure 6: J.G. Granö, at the age of 61 (1943) and cover of „Das Formengebäude des nordöstlichen Altai“ with dedication to Paul Fickeler. and trough valleys in Northern Central Asia. Also with all these publications he puts emphasis on scientific access for his German fellow geographers, manifested by extended abstracts/short versions in German (Granö, 1947 and 1949).

After having served as Rector of the University of Turku in 1932 - 1934, he assumes the position of Chancellor for a period of ten years.

Granö's research attracts a lot of attention in the German-speaking countries. In 1947 in Switzerland Annette Capt draws on his 1929 landscape formulas from "Reine Geographie". She applies them in the Kanton of Zurich and develops them further (Capt, 1947). In 1949 Hermann Lautensach pays tribute to his Finnish colleague in a very special way: His regional-geographic account of Madeira he entitles „... dedicated to the excursion enthusiast J.G. Granö“.

In 1950 it is of importance to the German Carl Troll to refer in his writings about landscape structure to J.G. Granö's term of „Kleinräume“ [„microtopes“]. He considers them as an equivalent to Granö's conception of smallest landscape complexes or units, the „Ökotope“ [„ecotopes"] (Troll, 1950).

In 1953 J.G. Granö attends the 125th anniversary celebration of the Gesellschaft für Erdkunde zu Berlin. Figure 7 shows his letter of thanks phrased in excellent German which is still kept in the Society's archive.

One year later the Gesellschaft für Erdkunde zu Berlin appoints J.G. Granö „in Würdigung seiner hervorragenden Verdienste um die Erforschung Zentralasiens und Finnlands " $[, \ldots, \ldots]$ as honorary member. In 1955 the Finnish geographer, this way honoured, publishes with "Die geographischen Provinzen Finnlands" [,The Geographic Provinces of Finnd,] in Geographische Rundschau for the last time a German-written article (Granö, 1955). Shortly before his 74th birthday, on 23 February 1956, he passes away in Helsinki. The obituary by Kaarlo Hildén is published in the Sitzungsberichte der Finnischen Akademie der Wissenschaften [Finnish Academy of Sciences] - in German (Hilden, 1956)! 


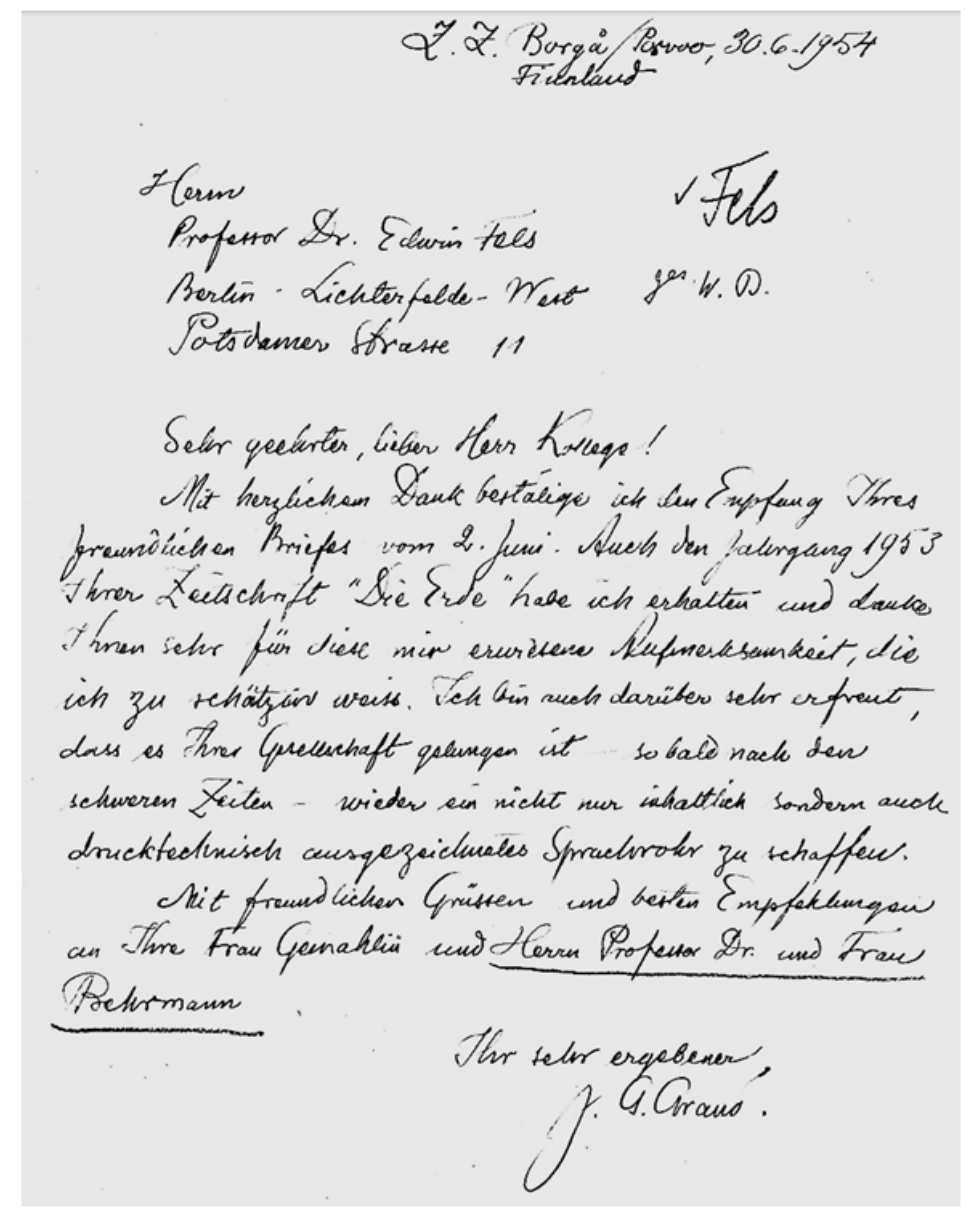

Figure 7: Letter of thanks of Granö to Prof. Edwin Fels, Geographic Society in Berlin, 1954.

Three years after J.G. Granö's death Josef Schmithüsen suggests within the scope of a systematic checking of the geographic science „sich im Sinne der 'Reinen Geographie' von J.G. Granö belastenderScheinprobleme zu entledigen" [,in the sense of the ,Reine Geographie' (,pure geography') of J.G. Granö to get rid of burden some bogus problems"] (Schmithüsen, 1959). Westermanns Lexikon der Geographie [the Westermann Encyclopedia of Geography] from 1969 states about J.G. Granö: „Mit seiner aus exakter Landschaftsanalyse aufgebauten landschaftlichen Synthese und Landschaftsgliederung hat er für die moderne Landschaftskunde wichtige Grundlagen geschaffen." [„,With his land-scape synthesis and landscape structurebased on an exact landscape analysis he has created important basics for landscape science."] (Westermanns, 1963), and in 1973 Karlheinz Paffen puts at the beginning of his collective volume entitled „Das Wesen der
Landschaft" ["The Character of the Landscape"] Granö's article "Geographische Ganzheiten" [„Geographic Entireties,,], at that time already almost 40 years old - and this, although already published in 1953, again drawing upon J.G. Granö, he had already pleaded for a landscape addressing which is significantly more reflecting the biologicalecological relationships (Paffen, 1973 and 1953). During the 1980s and 1990s Granö's fame vanishes more and more in German Geography. In 2004 it is then Eckart Ehlers who, in a review of the University of Tartu volume published on the occasion of the 120th anniversary of J.G. Granö's birthday, tries to bear in remembrance in German professional circles the „Erinnerung an einen grossen Geographen“ [,memory of a great geographer"] (Ehlers, 2004). Figure 8 gives an impression about the feedback on J.G. Granö's publications - also in the Germanspeaking region. 


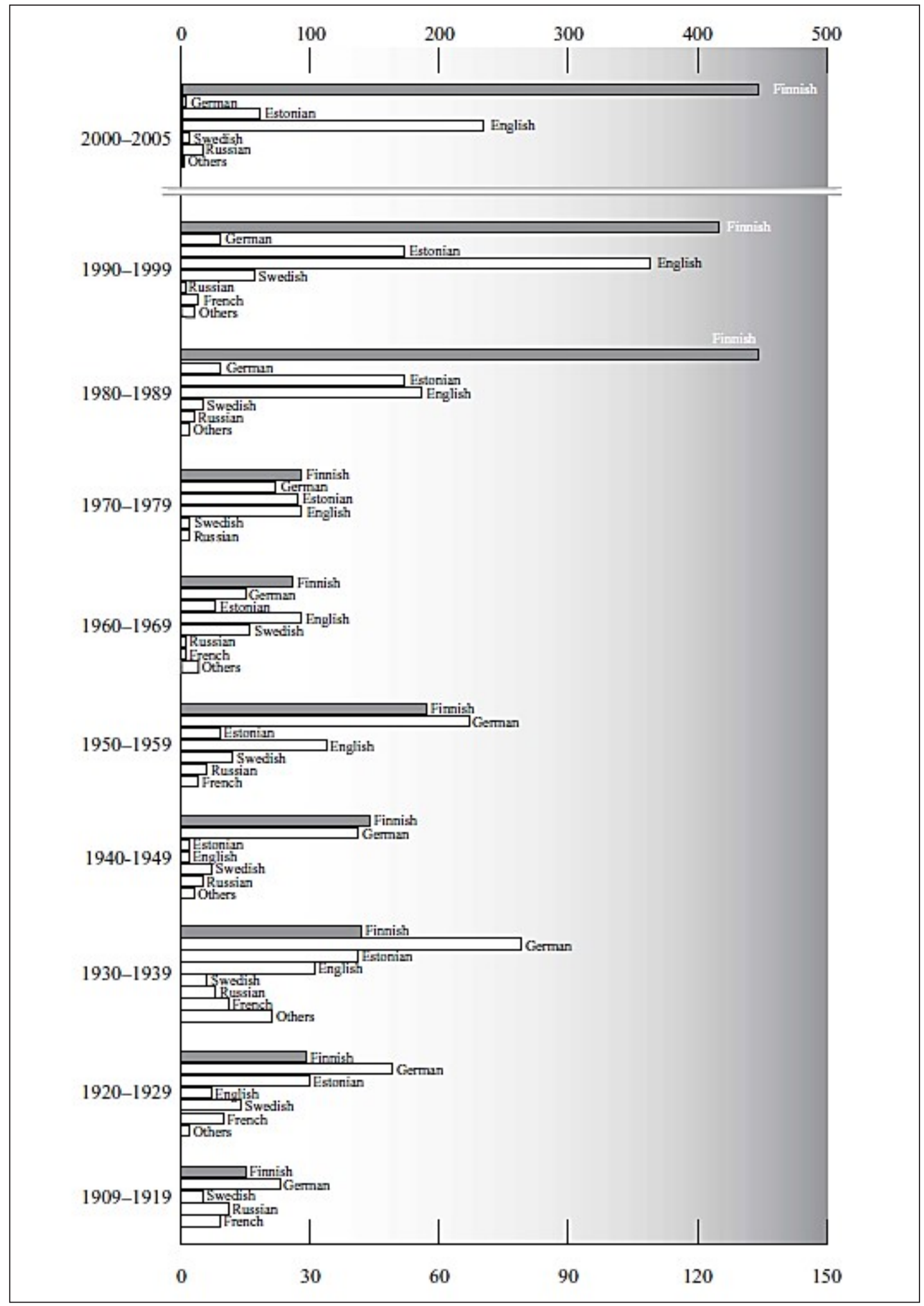

Figure 4. Distribution of works containing references to J. G. Granös publications (numbers of pages) in 1909-2005 by decade and language. "Other languages" refers to Italian, Dutch, Hungarian, Polish, Spanish, Turkish, Portuguese, Czech and Romanian. The numbers of pages appearing in Finnish and English have increased so sharply in 2000-2005 that the figures for these five years (about fifty years after his death) are practically equal to those for all the previous years put together. For this reason it has been necessary to present them on a different scale, indicated at the top of the diagram.

Figure 8: Statistics of references to publications of J. G. Granö (Granö, 2005). 


\section{Virtual Landscape Character. J.G. Granö Today Totally Trendy}

During the 1990s Granö's youngest son, Olavi, decides to publish an English version of his father's 1929 book "Reine Geographie" for the AngloAmerican market. In 1997 this plan is eventually materialised with support of the Granö connaisseur Anssi Paasi from University of Oulu, Finland. For the cover they decide for Figure 4 of "Reine Geographie“. Its captions reads: „Aussicht von dem am Nordrande des Altaigebirges sich erhebenden Berge Bobyrgan nach $\mathrm{N}$ wo die westsibirische Tiefebene sich 500$600 \mathrm{~m}$ weiter unten ausdehnt. Aufgenommen vom Verf. 1914“ [„View from Bobyrgan Mountain located at the northern margin of the Altai Mountains towards North into the West-Siberian lowland plain extending $500-600 \mathrm{~m}$ lower. Photograph by author, 1914“] (Figure 9).

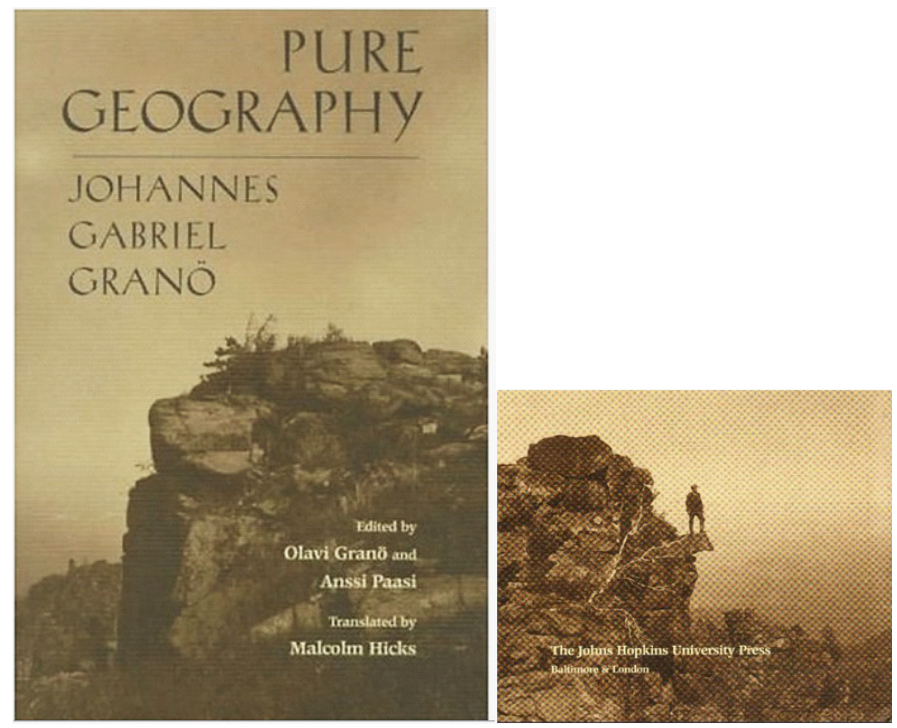

Figure 9: Front cover (left) and back cover of „Pure Geography“, 1997.

On its backcover Arnold R. Alanen from the University of Wisconsin writes: „Reading Pure Geography one is struck by the number of words and phrases with a distinctly contemporary viewpoint, as if the volume had been written very recently. Also timely is Grano's conception of the environment as a complex of phenomena perceived by the senses. As other geographers have noted, this book was decades ahead of its time."
The publication of „Pure Geography“ (Granö \& Paasi, 1997; Paasi, 1997; Golledge, 1998) triggers a strong interest in the works and ideas of J.G. Granö. This goes even as far as the organisation of an exhibition of his photographs from the Altai Mountains, e.g. in 2005 at the University of Minnesota Regis Center of Art in Minneapolis.

More recently, in 2014, Paulo Raposo und Cindy A. Brewer, Penn State University, put J.G. Granö with reference to his "Pure Geography" - in one line with leading representatives of modern landscape perception like Jay Appleton, Daniel Ellis Berlyne as well Rachel and Stephen Kaplan (Raposo \& Brewer, 2014) In this context it has, however, to be mentioned that the insights and ideas of the Finn date back to the 1920s whereas the publications of the others about the mentioned features stem from times half a century later.

In Europ it is mainly experts interested in the studies of the sound- and olfactory situations of the landscapes who deal with "Pure Geography“ (Bischoff, 2007; 2008; 2016).

In the year 2000, with support from the University of Turku (Finland), the J.G.Granö Centre, a memorial, museum and conference venue, is established in the 1930s style villa of the former Granö student and then successor August Tammekann.

Two years later, on the occasion of the 120th birthday of J.G. Granö, an international conference is held in Tartu (Granö, 2003). Amongst others, Anne Buttimer, University College Dublin, is one of the invited speakers there. For her, J.G. Granö is an "early herald for geographical research on environment perception"(Buttimer, 2002), and Martin Jones, University of Sheffield, states that he considers J.G. Granö with his ideas about rhythms and motions in landscapes a prerunner of the Hägerstrand School (Jones, 2003). The Swede Hägerstrand founded the so-called Time Geography in the 1970s and thus gave a lot of impulses, also into sociology.

Anssi Paasi, however, relativates that J.G. Granö's oeuvre has to be considered the origin of today's perception-thematic directions in geography: „The 


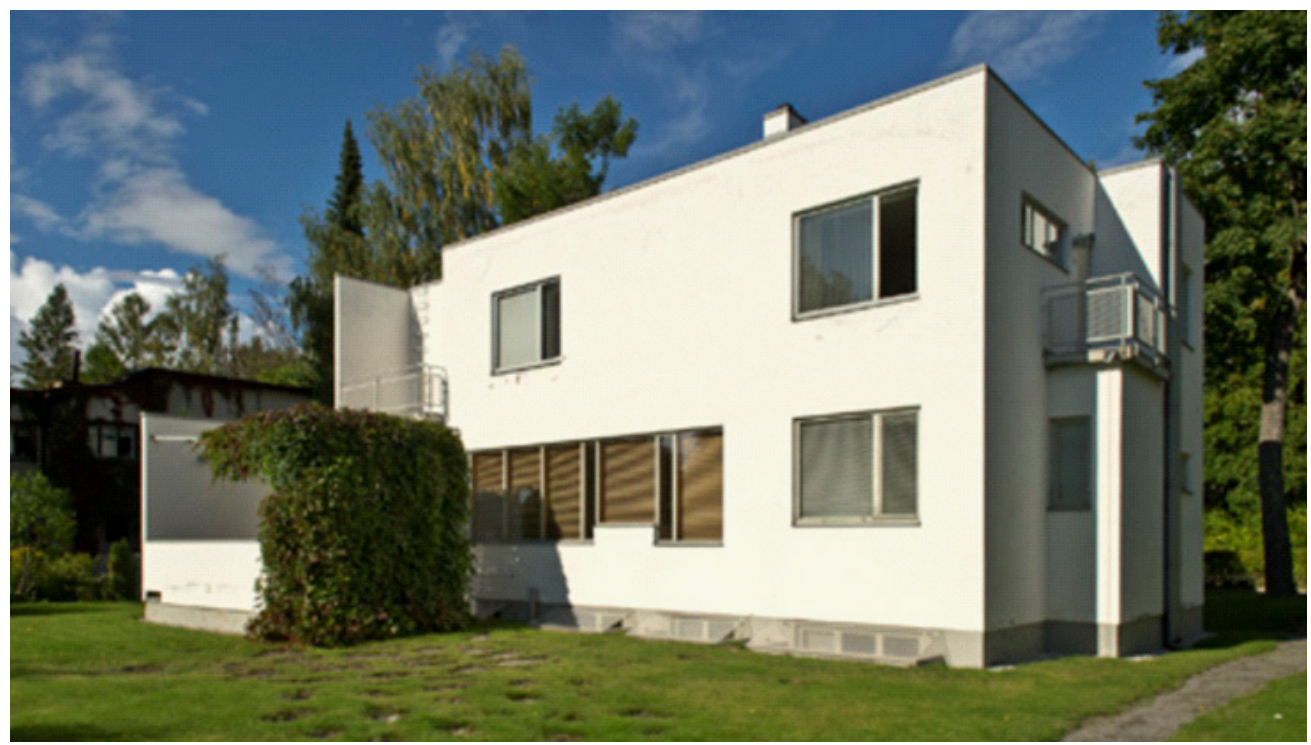

Figure 10: J.G. Granö Centre Tartu (photograph courtesy University of Turku).

experienced world was for him the perceptual world, which he understood as being the same for all people. Thus his concept of geography reduced the anthropocentric treatment of environments to a research-centred treatment" (Paasi, 1984).

This statement has also to be seen in the light of the landscape-physiognomic aspects continuously emphasized by J.G. Granö. These aspects are basically already established since Alexander von Humboldt's times and have been derived from Greek фúoıs

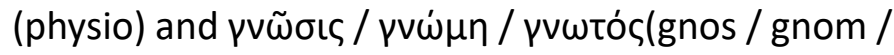
gnot) - in the sense of a cognition of the landscape constitution.

Already in his preface to "Reine Geographie“ (1929) J.G. Granö points out that for his work the physiognomically ascertainable and describable human environment was central. In "Die geographischen Gebiete Finnlands" (1931) he emphasizes in the context with his "Landschaftserfassung" [landscape ascertainment] that the latter is per se "physiognomisch, da wir bei ihrer Bestimmung nur die sichtbaren Züge beachten" [„physiognomical, since for their assignation we use only their visible features"] (Granö, 1931). In 1941 he even integrates this principle into the title of the article "Eine Geographie physiognomischer Typen und einheitlicher Räume" [„A Geography of Physiognomic Types and Homogeneous Spaces"] (Granö, 1941).
For the leading German landscape physiognomist of the post-worldwar II period, Herbert Lehmann, it is essential „,nach dem objektiven Landschaftscharakter einer bestimmten Gegend zu fragen, wenn man damit die äusseren Bedingungen meint, an die sich ein bestimmtes seelisches Erleben knüpft" [,to ask for the objective landscape character of a certain region when one talks about the outer conditions which a certain emotional experience is attached to"] (Lehmann, 1950). In this context, drawing upon Karlheinz Paffen, it is inevitable to point out the "ambiguity" of the term landscape physiognomy. Paffen categorically excludes the emotional viewing approach of Herbert Lehmann and others. For Paffen landscape physiognomy is „objektbezogen und bedeutet nichts anderes als das räumlich-gegenständliche, formale Erscheinungsbild der Landschaft, wie es sich aus der Gesamtheit der in der geographischen Substanz physiognomisch erfassbaren, geographischen Formen ergibt" [,object-related and means nothing else but the spatially objective, formal, visual appearance of a landscape, as derived from the entirety of the physiognomically ascertainable geographic forms within the whole geographic substance,,] (Paffen, 1973). This matches to a high degree the approach of J.G. Granö.

During the 1960s and 1970s the German-speaking Geography seems to loose interest in landscape 
physiognomy as a subject of research. In 1981 Ernst Neef from the Dresden University of Technology, Germany, finds fault with what he calls an „Entwertung desPhysiognomischen "[, devaluation of physiognomy“] and criticizes,,Dass eine Beschreibung physiognomischer Sachverhalte unwissenschaftlich sei oder ihr die für die Wissenschaft verbindliche Exaktheit und Eindeutigkeit fehle, kann nur jemand äussern, der die Funktion der Beschreibung als wichtiges Mittel der Datengewinnung mangels ausreichender Erfahrung nicht kennt" [„That the description of physiognomic facts and features is non-scientific or it lacks the binding accuracy and unambiguity necessary in science, can only be claimed by someone who, due to a lack of sufficient experience, does not know the role of description as a means of data acquisition,,] (Neef, 1981).

Admittedly, in the meantime the young disciplines of landscape architecture and landscape management are committed to the topic of overall landscape appearance, magisterially, however, - in particular in Germany -the nature conservation authority is responsible. Albeit, there dominate the views of the biologists. Drawing upon the European Landscape Convention (Florence, 2000), representatives of the German Bundesamt für Naturschutz [Federal Agency for Nature Conservation] state: „Die Bemühungen des Naturschutzes konzentrierten sich in der Vergangenheit im Wesentlichen auf den Arten- und Biotopschutz. Trotz eines expliziten gesetzlichen Auftrags blieben Landschaften als erlebbare Umwelt des Menschen, als Schutzobjekte weitgehend unberücksichtigt". [,In the past the efforts of nature protection primarily concentrated on species and biotope conservation. Despite an explicit legal mandate, landscapes - as tangible environment of humans - remained largely disregarded as protected areas."] They try to cope with this issue through a research and development project for the designation of landscapes worthy of protection (Finck et al., 2004). As a consequence, also a cartographic depiction originated. It demarcates almost half of the German terrain (45.3\%) as "Landschaften mit geringer Bedeutung“ ["Landscapes of low importance"] which implies that these areas are practically written-off. Out of
885 designated landscape units this only applies to 384. Since in this case for the evaluation primarily the occurence of particular biotopes and the distribution of endangered plant and animal species has been used, not even an at least partly deletion of the afore mentioned deficiency in the complex landscape addressing has been reached.

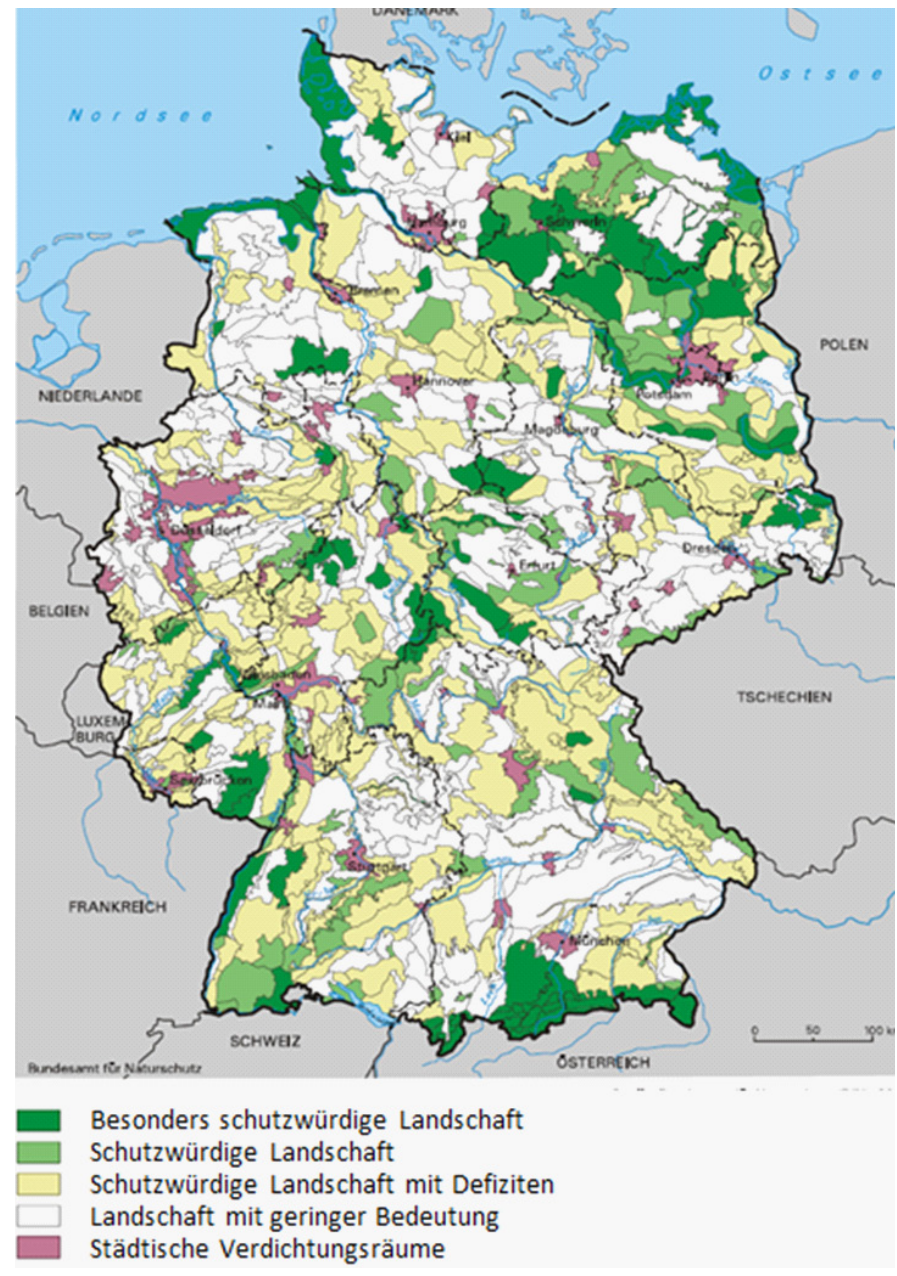

Figure 11: Nature protection-related assessment of German landscapes. Federal German Agency for Nature Conservation, 2012 (BfN, 2016).

The European Landscape Convention aims at „Landschaft in ihrer Gesamtheit und unabhängig von ihrem Wert zu schützen... Grundgedanke ist, dass alle Landschaften, egal welcher Güte, die Qualität der Lebensbedingungen der Menschen bestimmen und gestalten. Somit betrifft die Konvention nicht nur ausergewöhnliche oder unberührte Landstriche sowie ländlich geprägte Landschaften, sondern auch alltägliche, städtische und beeinträchtigte Landschaften.“ [„,protecting 
landscapes in their entirety and independent of their values ... Fundamental idea is that all landscapes, regardless their quality, determine and shape the quality of the human living conditions. Thus, the convention concerns not only exceptional or untouched tracts of land as well as rural landscapes but also ordinary, urban and affected landscapes."] (Jeschke \& Mandl, 2012). „Artikel 5 Punkt a) der Europäischen Landschaftskonvention verpflichtet die Vertragsparteien ausdrücklich, Landschaften als wesentlichen Bestandteil des Lebensraumes des Menschen ... und als Grundstein ihrer Identität rechtlich anzuerkennen ... Die Europäische Landschaftskonvention geht damit weit über deutsches Recht hinaus.“[,Article 5 Litera a) of the European Landscape Convention obliges the contractual parties explicitly to legally acknowledge landscapes as an essential component of the human biosphere ... and as cornerstone of their identity ... Thus, the European Landscape Convention goes far beyond the scope of German law."] (Schwahn, 2005).

Werner Nohl considers "das Landschaftsbild als regionales Identitätsangebot" [,the landscape appearance as regional offer of identity"] (Nohl, 2011) and criticises that the appreciation of landscapes concerning this matter „dem für die Entwicklung regionaler Identität so wichtigen Naturschutz abhanden gekommen ist" [„,got lost to nature conservation which is so important for the development of regional identity"] (Nohl, 2011). He describes the situation as a "LandschaftsbildVergessenheit“ [„oblivion of landscape appearances"] prevailing in wide circles. To his mind the main concern of thelarge majority of citizens is "für einige Stunden den technisch total überformten urbanen Wohn- und Arbeitsorten zu entkommen, und dazu reichen ihnen in aller Regel die angrenzenden Agrarund Waldlandschaften aus ... auch wenn sie agrarisch und forstwirtschaftlich intensiv genutzt werden" [,to escape for some hours from the technically totally reshaped urban residence and job locations, and for this usually the adjacent agricultural and forest landscapes are sufficient ... even if they are agriculturally and silviculturally intensively used."] (Nohl, 2007).
The European Landscape Convention (abbreviated ELC) was submitted for formal confirmation of participation by the Council of Europe to its 47 members in October 2000. While Switzerland belongs to the 18 first signatories and meanwhile also ratified the convention, Germany and Austria belong to those seven countries which still deny their participation (COE, 2016).

For Germany a participation has "seitens der Länder und der Bundesregierung bisher abgelehnt worden, weil wesentliche Impulse für den Umweltund Naturschutz durch die ELC nicht erwartet und daraus entstehende Verpflichtungen befürchtet wurden" [,so far been refused on the part of the Federal States and the Federal Government because essential impulses for environment and nature protection made by ELC were not expected and resulting commitments apprehended."] (Umweltministerkonferenz, 2013). The same applies to Austria (Salzburg.gv.at, 2016). Against the background of this article a paper of Hans Peter Jeschke and Peter Mandl in Klagenfurter Geographischen Schriften entitled „Eine Zukunft für die Landschaften Europas und die Europäische Landschaftskonvention“ [„,A Future for the European Landscapes and the European Landscape Convention,] is of great interest. Here the authors display a survey regarding the national landscape structure and classifications in Europe (Jeschke \& Mandl, 2012).

Their compilation (Table 1) shows the following situation: The bases date all back to the 1980s and 1990s - with one exception: Finland draws upon J.G. Granö 1925!

Granö's Finland map of 1925 bears the title "Charakteristika der Landschaft"["Characteristics of the Landscape"] (cf. Section 1, Fig.4) and in this sense puts all the features visually essential for a classification into the centre. This includes the vegetation types that dominate the landscape appearance, either alone or in combination - from a Central European view, primarily agriculture and silviculture, the formation of the relief and the settlement development. Water bodies, of 
Table 1: Overview of the national landscape structure and its classificationsin Europa 2003 (Jeschke \& Mandl, 2012), excerpt).

\begin{tabular}{|c|c|c|}
\hline Belgien & 1985 & Antrop, Mare \\
\hline \multirow[t]{2}{*}{ Dänemark } & 1987 & Nordischer Ministerrat \\
\hline & 1997 & $\begin{array}{l}\text { Moller, Per Grau; Porsmose, } \\
\text { Erland und Dorte Madsen }\end{array}$ \\
\hline Deutschland & 1998 & $\begin{array}{l}\text { Burggraaff, Peter und Klaus- } \\
\text { Dieter Kleefeld* }\end{array}$ \\
\hline \multirow[t]{2}{*}{ England } & 1997 & Countryside Agency \\
\hline & in Arbeit & English Heritage \\
\hline \multirow[t]{3}{*}{ Finnland } & 1925 & Grano. Johannes Gabriel \\
\hline & 1987 & Nordischer Ministerrrat \\
\hline & 1990er Jahre & $\begin{array}{l}\text { Comity of landscape } \\
\text { conservation }\end{array}$ \\
\hline Frankreich & in Arbeit & Lejanboule \\
\hline Estland & \multicolumn{2}{|l|}{ Keine Auskunft } \\
\hline Griechenland & \multicolumn{2}{|c|}{ Keine Gliederung vorhanden } \\
\hline Italien & \multicolumn{2}{|c|}{ Keine Gliederung vorhanden } \\
\hline Irland & \multicolumn{2}{|c|}{ Keine Gliederung vorhanden } \\
\hline Lettland & \multicolumn{2}{|l|}{ Keine Auskunft } \\
\hline
\end{tabular}

\begin{tabular}{|l|l|l|}
\hline Portugal & \multicolumn{2}{l}{ in Arbeit, keine weiteren Informationen verfugbar } \\
\hline Schortland & $1993 / 94$ & Scottish Nature \\
\hline Schweden & 1987 & Nordischer Ministerrat \\
\cline { 2 - 3 } & 1994 & Helmfried, Staffan \\
\cline { 2 - 3 } & 1995 & Sporrong, Ulf \\
\hline Schweiz & Keine Gliederung vorhanden \\
\hline Slowenien & 1998 & Marǔ̌ic, Janez, Ogrin, Dušan \\
& und Margita Jan i \\
\hline Ungarn & Keine Gliederung vorhanden \\
\hline Wales & Gliederung vorhanden; keine weiteren Informationen \\
\hline Portugal & in Arbeit, keine weiteren Informationen verfugbar \\
\hline Schottland & $1993 / 94$ & Scottish Nature \\
\hline Schweden & 1987 & Nordischer Ministerrat \\
\cline { 2 - 3 } & 1994 & Helmfried, Staffan \\
\cline { 2 - 3 } & 1995 & Sporrong, Ulf \\
\hline Schweiz & Keine Gliederung vorhanden \\
\hline Slowenien & 1998 & $\begin{array}{l}\text { Marušc, Janez, Ogrin, Dušan } \\
\text { und Margita Jan i }\end{array}$ \\
\hline Ungam & Keine Gliederung vorhanden \\
\hline Wales & Gliederung vorhanden; keine weiteren Informationen \\
\hline
\end{tabular}

prominent importance for Finland, represent a fourth group of physiognomic types. A compilation of this type would also be worth to be considered for an approximation to the intentions of the European Landscape Convention in the form of national overviews. In the afore mentioned survey of the German Federal Agency for Nature Conservation the built-up areas were reduced to the demarcation of larger urban agglomerations. Further, it completely declined the consideration of the georelief, although already in 1953 the German geographer HansGünter Gierloff-Emden had already emphasized the enormous importance of morphographic mapping for landscape characterization - drawing upon the seminal "Map of the Landforms of the United States" by Erwin Raisz (1939) (Raisz, 1939). Besides the work of his compatriot Herbert Lehmann during the 1930s, in this context Gierloff-Emden also refers to the results and statements of the two U.S.-American geographers Nevin M. Fenneman and Wallace W. Atwood from the late 1930s (Gierloff-Emden, 1952). In this context also the work of Harry Waldbaur (1957) has to be mentioned (Waldbaur, 1957).

The above statements shall be brought to conclusion with a proposal of a map showing physiognomic characteristics (Figures 12 and 13). Visual features of landuse and relief re displayed for all the landscape units defined by the German Federal Office for Nature Conservation (Bundesamt für Naturschutz). For these units alphanumerical abbreviations are generated. They can serve as a basis for landscape formulas as developed by J.G. Granö. 


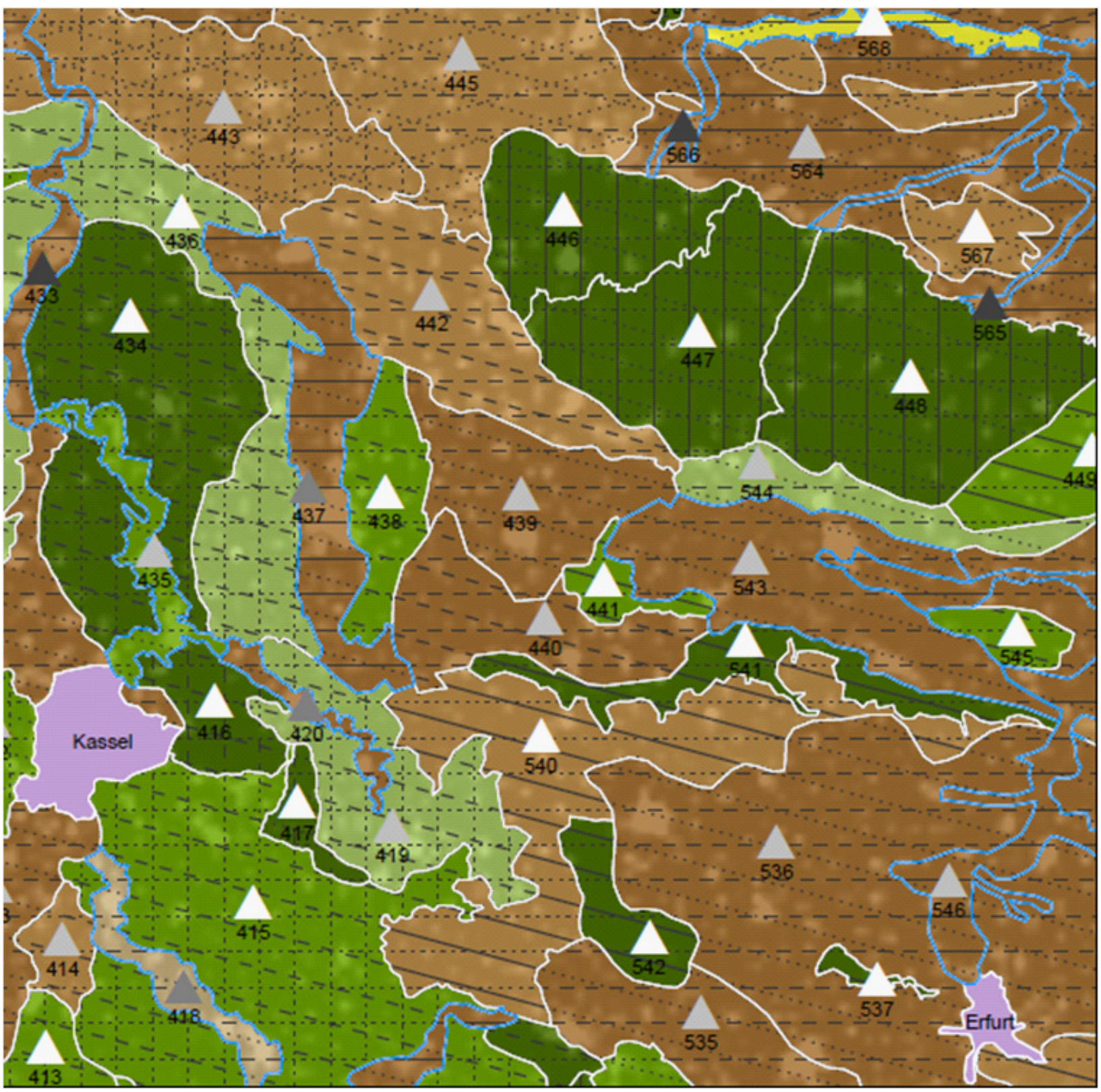

413 Homberger Hochiand 414 Knull 415 Fulda-Werra-Bergland 416 Kaufunger Wald 417 Hoher Meißner 418 Bebra-Melsunger Fuldatal 419 unteres Werratal 420 Tal der Werra 433 Hoizmindener Wesertalung 434 Solling, Bramwald und Rheinhardswald

435 Weserdurchbruchstal, Mundener Fulda-Werra-Talung 436 Sollingvoriand 437 Leine-lime-Senke 438 Göttingen-Northeimer Wald 439 Eichsfelder Becken 440 Unteres Eichsfeld (ohne Onmgebirge und Bieicheröder Berge) 441 Onmgebirge und Bieicheröder Berge 442 Südwestiches Harzvoriand 443 ith-Hils-Bergland 445 innerstebergland 446 Oberharz 447 Mittelharz 448 Unterharz 449 Östiche Harzabdachung 535 Westthüringer Berg- und Hügeliand 536 Thüringer Becken 537 Fahnersche Höhe 540 Ringau, Obereichsfeld sowie Südabdachung von Dün und Hainieite 541 Dün und Hainieite 543 Nordthüringer Hügelland 544 Südharzer Zechsteingürtel 545 Kyffhäuser 546 Gera-Unstrut-Heime-Niederung 564 Harzrandmulde 565 Bode-Holtemmetal 566 Okertal 567 Harlyberg-Falistein-Huyberg-Hakel-Blankenburger Erhebungen 568 Grosses Bruch

(Landschaftsgrenzen und -namen: ... Bundes amt für $N$ aturschut, https://geodienste. bfn.de/landschaften?lang=de)

Figure 12: Map displaying the visual landscape characterof central Germany following J.G. Granö’s conception (Kirkamm, 2011; portion of 1:800 000 original). 
Visuell ist die jeweilige Landschaftseinheit in der Flächennutzung vor allem charakterisiert durch:

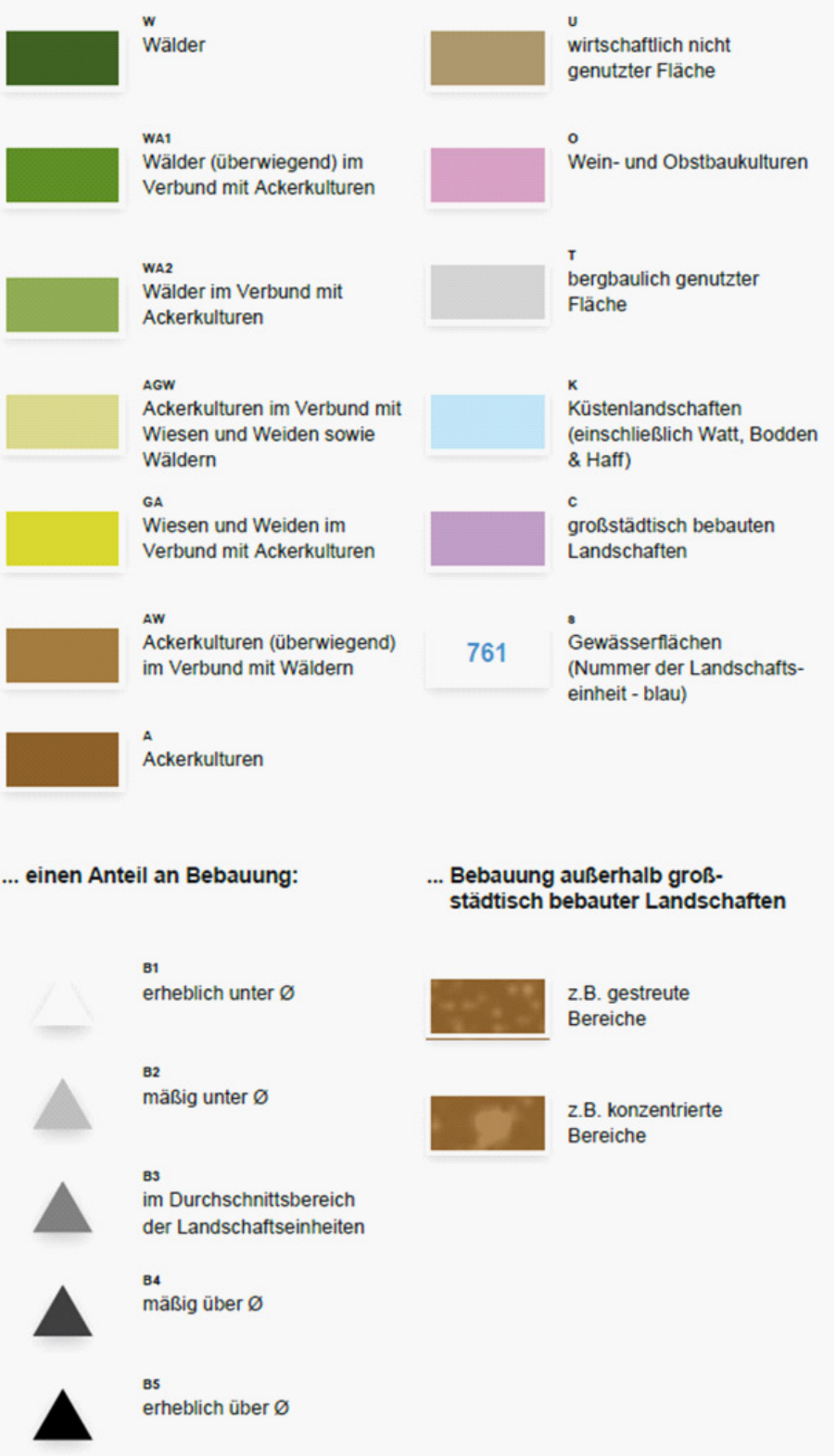

Visuell ist die jeweilige Landschaftseinheit in ihrer Geländeform charakterisiert durch:

Leitmerkmal

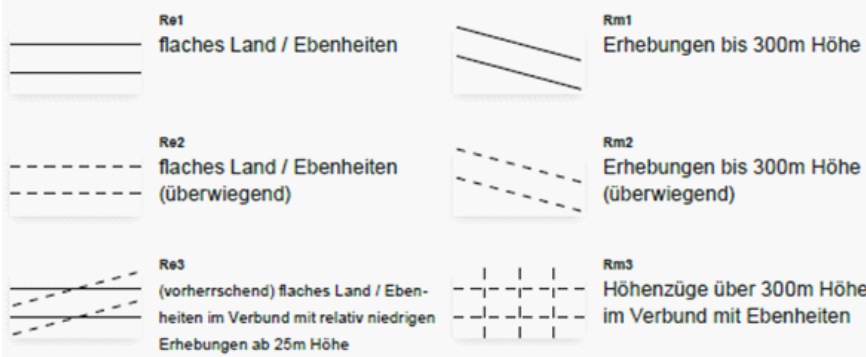

Re4

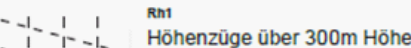
flaches Land / Ebenheiten im $z==-==-$
Erhebungen ab $25 \mathrm{~m}$ Höhe

Res

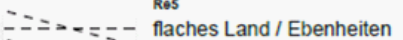

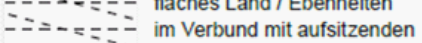
Erhebungen bis $300 \mathrm{~m}$ Hōhe

relativ niedrige Erhebungen ab $25 \mathrm{~m}$ Hōhe

Hōhenzūge über $300 \mathrm{~m}$ Hōhe (ūberwiegend)

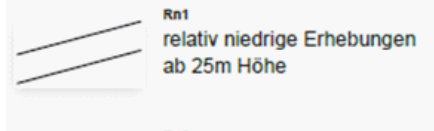

Rn2

relativ niedrige Erhebungen ab $25 \mathrm{~m}$ Hōhe (überwiegend)
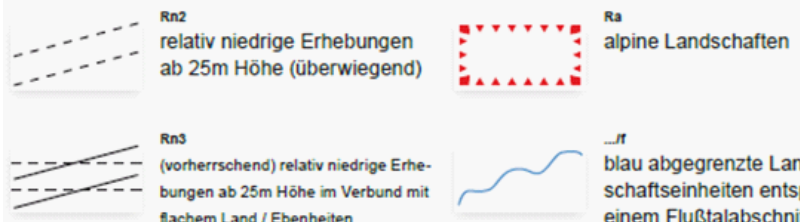
$\pi$ blau abgegrenzte Landschaftseinheiten entsprechen einem Flußtalabschnitt

Begleitmerkmal 1)

(e)

flaches Land / Ebenheiten

Erhebungen bis $300 \mathrm{~m}$

relativ niedrige Erhebungen

Höhenzūge über $300 \mathrm{~m}$

Die Gelāndeform wird ausschließlich durch Begleitmerkmale charakterisiert

Figure 13: Mapping key for the visual landscape characterisation following J.G. Granö's conception (Kirkamm, 2011). 


\section{Acknowledgements}

The present publication significantly gained quality through the critical comments of two reviewers of the submitted typescript. Their comments regarding both the paper's contents as well as the English phrasing are highly appreciated. Our thanks go to these individuals.

\section{References}

Bischoff, W. 2007. Wahrnehmungsgeographische Studien, Band 23.

Bischoff, W. 2008. „Grenzenlose Räume“ - Überlegungen zum Verhältnis von Architektur und städtischem Geruchsraum. In: Wolkenkuckucksheim, Heft 2/2008. http:// www.cloud-cuckoo.net/openarchive/wolke/ deu/Themen/052/Bischoff/bischoff.html (Date 11.4.2016)

Bruns, D. 2010. Die Europäische Landschaftskonvention - eine Aufforderung zu mehr Landschafts-Governance. Garten + Landschaft, 120. 2/2010: 33-35.

Bruns, D. 2006. Die Europäische Landschaftskonvention. Bedarf es eines deutschen Sonderweges? In: Stadt + Grün, 12/2006: 16-21.

BfN, Bundesamt für Naturschutz, https:// www.bfn.de/fileadmin/MDB/documents/ themen/landschaftsundbiotopschutz/ landschaftsbewertung_2011.pdf(Date 11.4.2016)

Burger, K. 1935. Der Landschaftsbegriff. In: Dresdner Geographische Studien. Heft 7/1935, S. 89

Buttimer, A. 2002. Geographers honour twentieth century pioniers. In: International Union Newsletter, 3/2002, S.101
Buttimer, A. 2010. Humboldt, Granö and Geo-poetics of the Altai. In: Fennia, Societas geographica Fenniae, 188/2010, S. 11-36

Capt, A.1947. Die Anwendung von Granös Methode zur Landschaftsgliederung am Beispiel des Kantons Zürich.

COE. http://www.coe.int/de/web/conventions/ full-list/-/conventions/treaty/176/signatures (11.4.2016)

Golledge, R.G. 1998. Review of Pure Geography. Journal of Regional Science 38: 4/1998, 677-682.

Ehlers, E. 2004. Granö, O.: Origin of Landscape Science. In: Erdkunde, 1/2004

Eisel, U. 2004. Landschaftliche Vielfalt mit und ohne Sinn. Über den Nutzen einer Methode in der Landschaftsplanung und im Naturschutz. In: Eisel,U. \& Körner, S. (eds.). 2006. Landschaft in einer Kultur der Nachhaltigkeit. Band 1. Die Verwissenschaftlichung kultureller Qualität. Arbeitsberichte des Fachbereichs Architektur Stadtplanung Landschaftsplanung. Heft 163. Universität Kassel. Kassel. S. 92-119.

Eisel, U. \& Körner, S. (eds.). 2006. Landschaft in einer Kultur der Nachhaltigkeit. Band 1. Die Verwissenschaftlichung kultureller Qualität. Arbeitsberichte des Fachbereichs Architektur Stadtplanung Landschaftsplanung. Heft 163. Universität Kassel. Kassel.

Fickeler, P. 1925. Der Altai. In: Dr. A. Petermanns Mitteilungen aus Justus Perthes 'Geographischer Anstalt, Ergänzungsheft 187/1925

Finck, P.; Gharadjedaghi, B. \& Riecken, U. 2004. Verbreitung und Gefährdung schutzwürdiger Landschaften in Deutschland. In: Natur und Landschaft, Heft 2/2004

Gierloff-Emden, H.-G. 1953. Die Bedeutung der morphographischen Karten in der Geographie. Die Erde, 1953, 3-4: 265 - 275. 
Granö J. G. 1905. Siperian suomalaiset siirtolat. (Referat in german) Die finnischen Kolonien in Sibirien. Fennia 22: 4, 1905

Granö, J.G. 1910. Beiträge zur Kenntnis der Eiszeit in der nordwestlichen Mongolei und einigen ihrer südsibirischenGrenzgebirge. Geomorphologische Studien in den Jahren 1905, 1906, 1907, und 1909. Fennia, Societas geographica Fenniae, 28: 5/1910, 1-230

Granö, J.G. 1922. Die landschaftlichen Einheiten Estlands. (Referat in german) in: LOODUS, 2/1922, S.119

Granö, J.G. 1929. Reine Geographie. Eine methodologische Studie beleuchtet an Bespielen aus Finnland und Estland. Acta Geographica 2/1929, S.116

Granö, J.G. 1931. Die Geographischen Gebiete Finnlands. Eine vergleichende Übersicht nebst methodischen Erörterungen. Publicationes Instituti Geographici Universitatis Aboensis (Turkuensis) 6/1931

Granö, J.G. 1934. Der Begriff des geographischen Gebietes. Die Grundlagen für die Begrenzung geographischer Gebiete. In: Comptes Rendus du Congrès International de Géographie de Varsovie, 1934, tome 4, Travaux de la section IV-VI, S. 199201

Granö, J.G. 1935. Geographische Ganzheiten. In: Dr. A. Petermanns Mitteilungen aus Justus Perthes' Geographischer Anstalt, 81/1935, S. 295-302 (Nachdruck in Paffen, 1973)

Granö, J.G. 1937. Gehöfte und Siedlungen in Finnland. Eine geographische Übersicht. Publicationes Instituti Geographici Universitatis Aboensis (Turkuensis) 15/1937
Granö, J.G. 1941. Mongolische Landschaften und Örtlichkeiten. Eine Geographie physiognomischer Typen und einheitlicher Raume nach Reisebeobachtungen und Wegeaufnahmen in Uranchai (Tannu-Tuwa) und der Nordmongolei aus den Jahren 1906, 1907 und 1909. Acta Geographica 7: 2/1941, S 1-291

Granö, J.G. 1945. Das Formengebäude des nordöstlichen Altai. Publicationes Instituti Geographici Universitatis Aboensis (Turkuensis) 20/1945, 1-362.

Granö, J.G. 1947. Uber die regionalgeographische Forschung und ihre Aufgaben in Finnland. Deutsches Referat in: Terra 59/1947, S. 31-32

Granö, J.G. 1949. Hochflächen und Trogtäler im nördlichen Zentralasien. Deutsches Referat in: Terra 61/1949, S. 160-161

Granö, J.G. 1955. Die geographischen Provinzen Finnlands. In: Geographische Rundschau, 1955

Granö, O. \& Paasi, A. 1997. Intellectuel and social contexts of J.G. Granö`s Pure Geographie. In: Pure Geography, 1997S. XIXXXVIII

Granö, O. (ed.). 2005. References to the work of J. G. Granö. Publicationes Instituti Geographici Universitatis Turkuensis 170/2005, 1-36.

Granö, O. (ed.). 2003. Origin of Landscape Science. J. G. Granö and a new pure geography for a new state a collection of papers. Publicationes Instituti Geographici Universitatis Turkuensis 167/2003, 7-34.

Granö, O. 2003. The radical reorientation of J.G.Granö's research work at the university of Tartu, Estonia, in 1919 -1923. S.17. In: Granö, O. (ed.): Origin of Landscape Science. J. G. Granö and a new pure geography for a new state a collection of papers. Publicationes Instituti Geographici Universitatis Turkuensis 167/2003 
Hard, G. 1964. Zur „erlebten Landschaft“. In: Die Erde. Zeitschrift der Gesellschaft für Erdkunde zu Berlin. Jg. 95. Heft 1. S. 26-35. Berlin.

Hard, G. 1970. Die "Landschaft" der Sprache und die "Landschaft" der Geographen. Semantische und forschungslogische Studien. Colloquium Geographicum, Bd. 11. Bonn.

Hard, G. 1995. Szientifische und ästhetische Erfahrung in der Geographie. Die verborgene Ästhetik einer Wissenschaft. In: Werlen, B. \& Walty, S. (eds.).1995. Kulturen und Raum. S. 4564. Zürich.

Haltenberger, M. 1932. (Referat in german):Granö, Johannes Gabriel zum 50. Geburtstag am 14. Marz 1932 gewidmet von seinen Schülern in Estland (Publ. Inst. Univ. Tartuensis Geogr. 20, 1933). In: Dr. A. Petermanns Mitteilungen aus Justus Perthes' Geographischer Anstalt, 1934, S. 231

Hassinger, H. 1930. Zur Methode der Landschaftsbeschreibung und Landschaftsgliederung. In Geographische Zeitschrift 5/1930, S. 293-296

Hilden, K. 1956. Johannes Gabriel Granö. Gedenkrede. In: Sitzungsberichte der Finnischen Akademie der Wissenschaften 1956, 77-87.

Jaeger, F. 1931. Granös Reine Geographie. In: Petermanns Mitteilungen aus Justus Perthes' Geographischer Anstalt, 1931, S.67

Jeschke, H. P. \& Mandl, P. (eds.). 2012. Eine Zukunft für die Landschaften Europas und die Europäische Landschaftskonvention. Klagenfurter Geographische Schriften, Heft 28/2012, S. 726

Jones, M. 2003. Human geographical landscapes: J.G. Granö`s approach to landscape as scientist and artist. In: Origin of Landscape Science. 2003, S. 98
Kirchhoff, T. \& Trepl, L. (eds.). 2009. Vieldeutige Natur. Landschaft, Wildnis und Ökosystem als kulturgeschichtliche Phänomene.

Kirkamm, H. 2011. Visueller Landschaftscharakter - Geographischer Vergleich und überregionale Kartierung. Diploma Thesis TU Dresden (unpublished), 2011

Lehmann, H. 1950. Die Physiognomie der Landschaft. In: Studium Generale, Heft 4/5, 1950, S. 188

Merisuo, A.K.1938. Itinerarien und Landschaftsprofile J.G. Granös aus Uranchai (Tannu-Tuwa) und der Nordmongolei. Acta Geographica 6/1938

Merzbacher, G. 1911. Zur Eiszeitfrage in der nordwestlichen Mongolei. In: Dr. A. Petermanns Mitteilungen aus Justus Perthes 'Geographischer Anstalt, 2. Halbband 1911, S. 18-19

Neef, E. 1981. Der Verlust der Anschaulichkeit in der Geographie und das Problem der Kulturlandschaft. Sitzungsberichte der Sächsischen Akademie der Wissenschaften zu Leipzig, MathematischNaturwissenschaftliche Klasse. Bd. 115, Heft 6. Akademie-Verlag. Berlin, 1981, S.17

Paasi, A. 1984. Connections between J.G.Granö’s geographical thingking and behavioral and humanistic geography. In: Fennia 1/1984, S. 30

Paasi, A.1997. Intellectual and social contexts of J.G.Granö`s Pure Geography. In: Pure Geography, 1997, XI-XXXVII

Paffen, K. 1953. Die natürliche Landschaft und ihre räumliche Gliederung. Eine methodische Untersuchung am Beispiel der Mittel- und Niederrheinlande. Verlag der Bundesanstalt für Landeskunde, S. 46

Paffen, K. (ed.). 1973. Das Wesen der Landschaft. Wege der Forschung, Bd. 39 
Passarge, S. 1931. Die Methode der Landschaftsbestimmung durch Symbole. In: Geographische Zeitschrift 1931, S. 230

Prechtel, N. \& Buchroithner, M.F. 2003. Establishing an Environmental GIS for Mountain Regions: The Altai Example. In: Proceedings of the Workshop "GIS Ostrava 2003" (January 26 - 29), CD Publication, 11.

Raisz, E. 1939. Map of the Landforms of the United States. Scale 1:4,625,000. In: Atwood, W.W. (1939/1940): Physiographic Provinces of North America. Boston (Ginn \& Copmany Publ.).

Raposo, P. \& Brewer, C.A. 2014. Landscape Preference and Map Readability in Design Evaluation of Topographic Maps with an Orthoimage Background. In: The Cartographic Journal Vol 51 No1, pp25-37/2014. DOI: 10.1179/1743277412Y.0000000027

Salzburg.gv.at. http://www.salzburg.gv.at/themen/ natur/naturschutzrecht-2/naturinternational/ landschaftskonvention (11.4.2016)

Schmithüsen, J. 1959. Das System der geographischen Wissenschaft. In: Berichte zur deutschen Landeskunde, Bd. 23/1959

Schrepfer,H. 1932. Die Geographischen Gebiete Finnlands. In: Dr. A. Petermanns Mitteilungen aus Justus Perthes 'Geographischer Anstalt, 1932, S. 204

Schrepfer,H. 1939. Gehöfte und Siedlungen in Finnland. In: Dr. A. Petermanns Mitteilungen aus Justus Perthes 'Geographischer Anstalt, 1939, S. 67

Terheyden, S. 1994. Das Leben eine Leihgabe. Paul Fickeler - Leben als Privatgelehrter. In: Siegerland, 3-4/1994, S, 102-105

Troll, C. 1950. Die geographische Landschaft und ihre Erforschung. In: Studium Generale, Heft 4/5, 1950
Vázquez Arias, C. E. 2013. Persistence of Physical Patterns of a Mountain Landscape Detection and Map Representation. MSc Thesis, Inst. Cartography, TU Dresden, 86 pp., 2013

Umweltministerkonferenz. Ergebnisprotokoll der 81. Umweltministerkonferenz 2013, S. 8

Waldbaur, H.1957. Landformen im mittleren Europa. Morphographische Karte mit Reliefenergie" 1:2 000000 Westermanns Lexikon der Geographie. 1963, S. 988

Yli-Jokipii, P. 1991. Die deutsche Konnexion in der finnischen Geographiewissenschaft. In. Acta Wasaensis 8/1991, S.163-164 